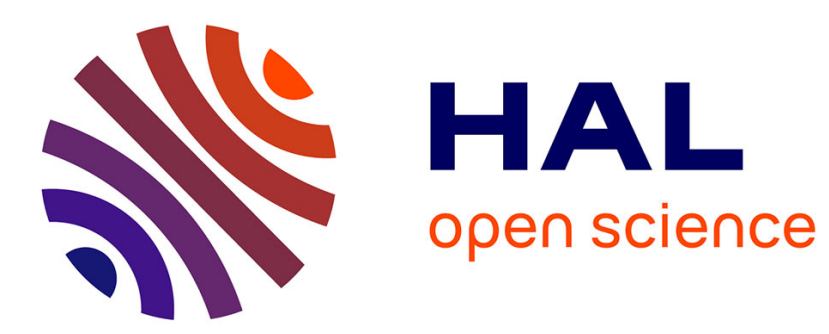

\title{
Antibiotic Adjuvants: Make Antibiotics Great Again!
}

\author{
Hana Douafer, Véronique Andrieu, Otto Phanstiel, Jean Michel Brunel
}

\section{To cite this version:}

Hana Douafer, Véronique Andrieu, Otto Phanstiel, Jean Michel Brunel. Antibiotic Adjuvants: Make Antibiotics Great Again!. Journal of Medicinal Chemistry, 2019, 62 (19), pp.8665-8681. 10.1021/acs.jmedchem.8b01781 . hal-02262519

\section{HAL Id: hal-02262519 https://hal-amu.archives-ouvertes.fr/hal-02262519}

Submitted on 25 May 2020

HAL is a multi-disciplinary open access archive for the deposit and dissemination of scientific research documents, whether they are published or not. The documents may come from teaching and research institutions in France or abroad, or from public or private research centers.
L'archive ouverte pluridisciplinaire HAL, est destinée au dépôt et à la diffusion de documents scientifiques de niveau recherche, publiés ou non, émanant des établissements d'enseignement et de recherche français ou étrangers, des laboratoires publics ou privés. 


\title{
Antibiotic adjuvants: Make antibiotics great again!
}

\author{
Hana Douafer ${ }^{1}$, Véronique Andrieu ${ }^{2}$, Otto Phanstiel IV ${ }^{3}$ and Jean Michel Brunel ${ }^{1 *}$
}

\author{
${ }^{1}$ Aix Marseille Univ, INSERM, SSA, MCT, Marseille, France. E-mail : bruneljm@yahoo.fr \\ ${ }^{2}$ Aix Marseille Univ, IRD, APHM, MEPHI, IHU Méditerranée Infection, Faculté de Médecine et de \\ Pharmacie, Marseille, France. \\ ${ }^{3} 12722$ Research Parkway, College of Medicine, University of Central Florida, Orlando, FL 32826 USA
}

\begin{abstract}
During the last decades, multiple approaches have been developed to combat bacterial resistance. However, the combination of antibiotic resistance mechanisms by bacteria and the limited number of effective antibiotics available, decreases the number of the interventions for the treatment of current bacterial infections. The solution to emerging antibiotic resistance will likely involve combination therapies of existing antibiotics and smart adjuvants, which re-empower the antibiotic agent to become efficacious against the resistant strain of interest. In this context, amphiphatic molecules provide the opportunity to target difficult-to-traverse bacterial membranes. We will depict herein that a reasoned adjuvant design permits to perform polypharmacy on bacteria by not only providing greater internal access to the co-dosed antibiotics but also by de-energizing the efflux pumps used by the bacteria to escape antibiotic action.
\end{abstract}

\section{Introduction}


Since the first isolation of penicillin by Alexander Fleming in 1940, antibiotics have been one of the most important discoveries in clinical therapeutics. ${ }^{1}$ However, the combination of antibiotic resistance mechanisms by bacteria and the limited number of effective antibiotics available, decreases the number of the interventions for the treatment of current bacterial infections (Figure 1). In order to minimize the emergence of resistance, potentiate the action of already existing antibiotics and facilitate the development of new antibiotics, it is necessary to understand the strategies used by bacteria to circumvent antibiotics and their specific mechanisms of action. ${ }^{2}$

Thus, an antibiotic will be functional if three conditions are fulfilled: a) the target of the antibiotic is present in the bacterial cell and intact, b) the antibiotic reaches its target in sufficient quantity to elicit the desired biological effect and c) the antibiotic does not undergo a change that makes it inactive. The alteration of one of these conditions will result in a bacterial resistance towards the antibiotic. This resistance may occur via different mechanisms (Figure 2) such as: a) target modification through a mutation, b) decreased permeability of the bacterial cell to the antibiotic, which is the most common cause of intrinsic resistance, c) reduction of the antibiotic influx or increase of its efflux, to prevent it from reaching its target in sufficient quantity and d) deactivating processes which degrade the antibiotic such as enzymatic hydrolysis or any other chemical modification that reduces the affinity of the antibiotic to its target. ${ }^{1,3}$ This report will review the common resistance mechanisms and provide new strategies as to how to move forward in this modern era of increasing bacterial resistance.

\section{Antibiotic resistance}

\section{1) Target modifications}

Target modification constitutes one of the most important mechanisms of resistance developed by the bacteria. In this case, the modification of the molecular target takes place following a point 
mutation in selected genes causing rapid resistance as it directly affects target structure in the microbes. ${ }^{1}$ In all the major cases, these mutational changes result in a reduction of susceptibility to inhibition while retaining the cellular functions of the target. Alternatively, some modifications of the latter are accompanied with other changes in the cell to compensate for the new characteristics of the modified target. ${ }^{1,3}$

It is also noteworthy that not only a mutation but also a highly effective enzymatic catalysis and regioselective alterations can be at the origin of the target modification. ${ }^{1,3}$ Thus, since the interaction of the antibiotic with its target is complementary, the slightest structural alteration of the target will have significant effects on the binding to antibiotics. For example, an alteration of the $30 \mathrm{~S}$ or $50 \mathrm{~S}$ subunit of the ribosome generates an antibiotic resistance targeting protein synthesis with respect to macrolides, tetracycline and chloramphenicol.

\section{2) The efflux pumps}

Another mechanism of resistance is the active expulsion of antibiotics from the interior of the cell. This resistance is accomplished by specific transport proteins called efflux pumps which are involved in the elimination of toxic substances. ${ }^{4}$ This type of resistance mainly affects antibiotics (in particular macrolides, tetracyclines and fluoroquinolones) that exert their action inside the cell, and inhibit the biosynthesis of proteins and DNA. ${ }^{3-5}$ The efflux pumps differ in their specificity and mechanisms ${ }^{3-5}$ where some specifically export only one molecule, others are called broadspectrum and are capable of expelling structurally-distinct classes of molecules thus defining multiple resistance..$^{3,6-8}$

These pumps are classified into five families: the ATP-Binding Cassette (ABC) family, the Small Multidrug Resistance (SMR) family, the Major Facilitator Superfamily (MFS), the Multidrug And Toxic-compound Extrusion (MATE) family, and the Resistance-Nodulation-cell Division (RND) family. ${ }^{3,6-8}$ This classification takes into account the number of units that make up the pump (single 
or multiple), the energy source used and the nature of the substrate exported. ${ }^{8}$ The phenomenon of antibiotic efflux is an "active" mechanism that requires energy for the movement of compounds against the concentration gradient, it is noteworthy that all the efflux pumps families use the proton driving force except for the $\mathrm{ABC}$ family which uses the energy provided by the hydrolysis of ATP. $^{7,9}$

\section{3) Inactivation of the antibiotic}

Several strategies have been developed by bacteria to diminish the effect of antibiotics and involve enzymes capable of modifying or degrading the antibiotic's architecture through hydrolysis reactions, group transfers and redox mechanisms. ${ }^{3}$

a) Antibiotics hydrolysis

This defense mechanism is facilitated by the presence of hydrolysis-sensitive chemical bonds (e.g., ester or amides bonds) that are the target of many enzymes excreted by the bacteria and able to cleave these bonds, leading subsequently to the inactivation of the antibiotic before it reaches its target. ${ }^{3}$ The development of such effective catalysts demonstrates the power of bacterial defense mechanisms against antibiotics. ${ }^{10}$

b) Beta-lactamases

Many enzymes are capable of altering or destroying antibiotics and beta-lactamases represent the most critically and clinically widespread enzymes of resistance. ${ }^{11}$ They are responsible for the hydrolytic cleavage of the beta-lactam present in penicillin derived antibiotics. The beta-lactam is the key structural element responsible for antibiotic activity because they irreversibly acylate the Penicillin-Binding Proteins (PBPs) that cross the bacterial wall. Thus, $\beta$-lactamases hydrolyze almost all $\beta$-lactams, including those present in cephalosporins, carbapenems and monobactams and generate products of open-cycle hydrolysis which are microbiologically inactive. ${ }^{11-13}$ The 
genes encoding these enzymes are widespread in the bacterial kingdom and are carried on chromosomes or plasmids. ${ }^{11}$ Moreover, Gram-negative bacteria release their $\beta$-lactamases into the periplasm to prevent the antibiotic from reaching their PBP target in the cytoplasmic membrane, ${ }^{12}$ while Gram-positive bacteria secrete their enzymes to the extracellular space. ${ }^{11}$

It is noteworthy that there are hundreds of beta-lactamases, all of which have the same function and the only difference lies in the amino acid sequences influencing their affinity for the different substrates. They are classified by two different methods: a structural classification (of Ambler) and a functional classification (of Bush-Jacoby). ${ }^{11,13}$

Repeated use of $\beta$ lactam antibiotics stimulated the synthesis of particularly troublesome enzymes called Extended-Spectrum Beta-Lactamases (ESBL), which attack and degrade most lactams. ${ }^{11,14}$ To date, more than 180 different ESBL were identified especially in Escherichia coli, Klebsiella pneumoniae, and Proteus mirabilis. ${ }^{15,16}$

The absence of chemical functional groups sensitive to hydrolysis in the chemical structure of aminoglycosides allows them to escape from the action of beta-lactamases. However, the bacteria have developed other classes of enzymes capable of disabling these protein synthesis inhibitors by decorating the periphery of aminoglycosides with three types of chemical substituents to prevent their binding to ribosomal RNA (Figure 3).

\section{c) The genetics of resistance}

Studies in a variety of micro-organisms have revealed the presence of numerous genetic loci involved in antibiotic resistance. ${ }^{3}$ The genes responsible for resistance are varied likely because the antibiotic has several different targets in the cell (any one of which may affect its potency) and because some targets require the expression of many genes at once. ${ }^{3}$ 
Two types of resistance are: a) natural resistance, which is an innate property specific to the bacterium as a result of intrinsic structural and functional characteristics and b) acquired resistance, which results either from a mutation of the bacterial genes or from the acquisition of foreign resistance genes or a combination of these two mechanisms. ${ }^{17,18}$

a) Resistance by mutations. Bacterial resistance can be acquired as a result of mutations in genetic information. These mutations result from errors in DNA replication, they appear continuously and independent of the presence or absence of an antimicrobial agent. ${ }^{19-21}$ Obviously, repair mechanisms exist and constantly intervene to correct these replication errors. However, some of the occasional mutations are positively selected for in the presence of antibiotics. The bacteria that carry these mutations resists the inhibitory action of the antibiotic, survive, proliferate and become the predominant type while susceptible bacteria are inhibited and disappear. ${ }^{19} 22$

b) Transferable resistance. The bacterial genome consists of elements bearing the genetic information necessary throughout the life cycle of the bacterial cell. Beyond chromosomes, accessory genetic elements such as transposons and plasmids play an important role in ensuring the survival of the bacterium. ${ }^{19,23}$ Since the chromosomes can be inherited vertically from a bacterium to offspring and the accessory genetic elements can be transmitted horizontally to other nearby bacteria ${ }^{23}$, the resistance can be transferred from a bacteria to the other in a quick and easy way by transferring plasmids, bacteriophages, naked DNA or transposons. ${ }^{23,24}$ This ability to share newly-acquired resistance genes by both vertical and horizontal gene transfer is a daunting challenge in combating antibiotic resistance.

It is noteworthy that the transfer of resistance genes can occur according to three mechanisms. The first deals with conjugation which requires a close physical contact between the two bacteria, where the adhesion of bacteria to each other facilitates the transfer of plasmids, resistance genes and 
transposons. In these cases, resistance genes can be carried on a conjugated plasmid, a transposon carried on a conjugated plasmid, or a conjugative plasmid that is mobilized on a chromosome. ${ }^{25}$ The second mechanism is based on transduction, which consists of the accidental incorporation of bacterial DNA initially carried on a chromosome or plasmid, into a bacteriophage or a virus. These gene carriers/ vectors can transmit the genes of resistance to other cells. ${ }^{19,26}$ The third possible mechanism is via transformation which involves the absorption of naked DNA generated by the decomposition of bacterial cells. ${ }^{19}$

\section{I) Adjuvants to antibiotics}

In this context, the spread of resistant Gram-negative bacterial strains is a growing public health concern, which renders life-saving drugs less effective. Thus, there is an urgent need for guidelines to develop agents that can penetrate both outer and inner membranes of these bacteria. It is evident that drug permeability in Gram-negative bacteria is more challenging for antibiotics with cytosolic targets, as they must transit across two protective lipid bilayers. The phospholipid bilayer that comprises the inner membrane greatly limits the diffusion of hydrophilic molecules. Compared to the Outer-Membrane (OM), hydrophobic molecules easily pass through the Inner-Membrane (IM) by passive diffusion.

During the last twenty years, four main therapeutic approaches were envisioned in order to delay the development of antibiotic resistance: (i) an anti-virulence therapy where agents that are not bactericidal indirectly inhibit the molecular pathway responsible for bacterial communication, (ii) a combination therapy where clinicians prescribe two or more antibiotics concomitantly during treatment to ensure the coverage of all possible bacterial pathogens and resistance profiles, (iii) the development of molecular antibiotic-hybrids by fusing different biologically active agents into one 
heteromeric entity with the hope of retaining the biological actions of the constituent fragment and (iv) an antibiotic-adjuvant combination approach.

This review deals exclusively with the antibiotic-adjuvant combination strategy and does not cover these already well-reviewed approaches. ${ }^{27}$

The combination of antimicrobial drugs has already been used in clinical therapy to cover a wider spectrum of microbes, achieve better efficacy or overcome treatment resistance. ${ }^{28,29}$ These combinations have represented effective and successful strategies to preserve the efficacy of current antibiotics, the result is a better efficacy while minimizing the necessary concentrations. ${ }^{30}$ Nevertheless, due to the emergence of Multidrug Resistant (MDR) bacterial strains, it is important to envision a new strategy.

Combining antimicrobial drugs with chemical entities that do not possess any antimicrobial action can be used to obtain a synergistic effect by targeting different steps in the biochemical process, improving the entrance or suppressing efflux of the antibiotic. ${ }^{29,31}$ Indeed, researchers have investigated the use of combinations of compounds devoid of antimicrobial activity to preserve existing antibiotics and potentiate their action. These peculiar compounds are called "adjuvants". The concept of antibiotic adjuvants deals with the ability of a molecule to potentiate and improve the effect of an antibiotic against a resistant microbial agent. ${ }^{32}$ Also called "resistance circuit breakers", "chemosensitizers" or "antibiotic potentiators"33,34, adjuvants are compounds without clean antimicrobial activity, although they can exert a slight inhibitory action of bacterial growth. In short, one can consider that once co-administered with an antibiotic they "suppress" the resistance and "improve" the inhibitory effect. ${ }^{31,35}$

They can be classified depending on the resistance mechanism to which they oppose. For example, one can distinguish $\beta$-lactamase inhibitors as molecules which prevent the degradation of the drugs 
before they reach their targets. Alternatively, efflux pumps inhibitors prevent drugs from being expelled outside and outer membrane permeabilizers aim to increase the number of molecules that penetrate the bacteria.

Nevertheless, depending on the action carried out (and the target) one can distinguish three groups in the literature:

a) Group 1. The first group of adjuvants which have an intrinsic antibacterial activity exerted directly on the bacterial cell ${ }^{36}$ and

b) Group 2, the second group consisting of compounds called "auxiliary compounds" that alter the permeability of the antibiotic pathogen ${ }^{37,38}$ as well as compounds named "macrophage modulators" that potentiate the destructive power of macrophages responsible for the phagocytosis of the microorganism. ${ }^{39}$

A third classification (Group 3) has also been suggested based on the nature of the target.

Group 3A is reserved for adjuvants that exert their action directly on the target (reduction of permeability, blockage of metabolic pathways and disturbance of bacterial physiology...).

Group 3B: for adjuvants that potentiate the activity of antibiotics by affecting the properties of the host.

It is noteworthy that of the adjuvants described in Group 3 subclass A are the only ones used in clinics, whereas those of Group 3B are currently explored in pre-clinical models. ${ }^{29}$

\section{$\beta$-lactamase inhibitors}

The almost unlimited ability of bacteria to survive under adverse conditions has allowed them to circumvent the inhibitory action exerted by antibiotics. The production of enzymes capable of 
hydrolyzing antibacterial molecules is one of these survival mechanisms. ${ }^{40}$ Thus, bacterial strains producing beta-lactamases, enzymes with destructive ability to $\beta$ lactams have severely limited their long term therapeutic application. With the exponential increase in newly described betalactamases, the world is witnessing an urgent and continuous demand for beta-lactamases inhibitors in order to withstand the escalation of bacterial attacks against beta lactam based therapeutics. ${ }^{41}$

Depending on the type of inhibition exerted (reversible or irreversible), these inhibitors are classified into two different types. Reversible inhibitors bind to the enzyme on an interim basis allowing the enzyme to eventually be restored. These agents are involved in a dynamic equilibrium and a reduction in their inhibitory effect is susceptible to simple dilution of the inhibitor. Alternatively, irreversible inhibitors use the structure of the beta lactam to attach themselves to or near the active site of the enzymes and can inhibit enzyme function. ${ }^{40}$

The first to be described and introduced as clinical therapeutics in the 1970s was clavulanic acid followed by sulbactam. The last introduced to the market was tazobactam which was described in the early 1980 and approved in 1993 in association with piperacillin. ${ }^{40,42}$ It is noteworthy that only these three inhibitors are currently available on the market ${ }^{43}$ as combinations with antibiotics under the following trade names: Augmentin (amoxicillin + clavulanate), Timentine (ticarcillin + clavulanate), Unasyn (ampicillin-sulbactam) and Zosyn (piperacillin + tazobactam (Figure 4).

The best-known combination, Augmentin is an oral antibacterial combination consisting of amoxicillin and the potassium clavulanate $\beta$-lactamase inhibitor, used in the treatment of a wide range of conditions from bronchitis to Lyme disease. ${ }^{44}$ It acts synergistically with amoxicillin to prevent bacterial growth by forming an irreversible bond with the $\beta$-lactamases functional site. Poorly active against pathogens, potassium clavulanate efficiently inhibits many types of the ESBL family ${ }^{45}$ able to hydrolyze penicillins, monobactams and cephalosporins. ${ }^{46,47}$ Clinicians considered 
that $\beta$-lactam antibiotics constituted an ideal therapeutic approach due to their efficacy and good tolerability, but the increasing resistance slowed down the enthusiasm of the scientific community mainly due to the global spread of bacterial $\beta$-lactamase-encoding genes. Thus, the design of numerous adjuvants such as avibactam in 2015 or vaborbactam in 2017 which inhibit $\beta$-lactamases appears crucial for maintaining good clinical effectiveness of the $\beta$-lactam class of antibiotics. ${ }^{48-51}$ Today, research continues in this field and four new combinations, three of which encompass a new class of inhibitors that are not beta-lactam are undergoing the final stages of clinic development before being allowed on the market. ${ }^{43}$ The choice of the inhibitor to be combined with $\beta$-lactam is a complex process that takes into consideration several criteria (Figure 5, Table 1): a) the inhibitor's ability to protect the antibiotic against enzymatic hydrolysis, b) the amount of inhibitor needed to ensure this protection and c) the possibility and stability of this combination. Among the research carried out in this field, the combination of stigmasterol steroid $\mathbf{1 6}$ with ampicillin lead to a clear improvement in the susceptibility of all the $\beta$ lactam resistant bacterial strains tested. This synergy was validated by evaluating the fractional inhibitory concentration index (FIC) that was less than 0.5 suggesting that stigmasterol can restore the activity of ampicillin by inhibiting beta lactamases. ${ }^{52}$

In a similar approach, English et al. reported a new semisynthetic inhibitor 17 called CP-45.899

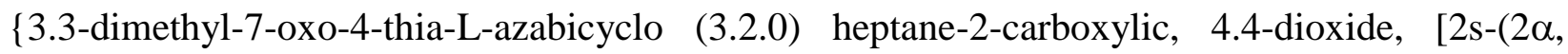
$5 \alpha)]\}$, that allowed the reduction of the amount of ampicillin necessary to inhibit the growth of resistant strains at a same level as that necessary against sensitive ones.

It is noteworthy that an impressive synergistic activity of this combination was observed against strains producing penicillinases such as S. aureus, H. influenzae, N. Gonorrhoeae, and $K$. pneumoniae and against cephalosporinases-producing strains notably those of B. fragilis. 
Nevertheless, E. coli and E. Cloacae strains appeared resistant to the CP-45.899-ampicillin combination. Furthermore, CP-45.899 allows for the potentiation and expansion of the spectrum of antibacterial activity of other $\beta$-lactams such as penicillin G, Carbenicillin and Cefazolin. Indeed, CP-45.899 has appeared much more stable than clavulanic acid in all tested conditions, with a half-life greater than $100 \mathrm{~h}$ and very high solution stability at $37^{\circ} \mathrm{C} .^{53}$

Currently, beta-lactamases inhibitors approved for clinical use are unable to inhibit both the growth of class A penicillinases and class C cephalosporinases-producing bacteria. In 2004, a new bicyclo[3.2.1] diazabicyclooctanone bridged compound, AVE1330A 18, was identified with an inhibitory power covering a wide range of beta-lactamases and better than that exerted by clavulanic acid, tazobactam or sulbactam against the enzymes TEM-1 and P99. ${ }^{54}$ AVE1330A activity was studied against a panel of isogenic E. coli strains and the Minimum Inhibitory Concentration (MIC) of the ceftazidime/AVE 1330A combination was not affected by the large amount of enzyme proportional to the size of the bacterial population. This finding illustrated the ability of AVE 1330A to efficiently protect ceftazidime from the attack of $\beta$-lactamases produced by the Gram-negative bacteria. ${ }^{54}$ Beta-lactamases are classified into four classes according to structural criteria on the one hand and their mechanisms of action on the other hand, three of them (serine-lactamases (SBL) Class A, C and D) use in their mechanisms a serine active site whereas class B uses divalent metal cations $(\mathrm{Zn})$ during the hydrolysis of the antibiotic and are called "metallo-beta-lactamases (MBL)". One of the major concerns is the search for molecules capable of inhibiting both the $\beta$-lactamases enzyme classes.

Although double-acting molecules are difficult to develop given the large mechanistic and structural differences between the two classes, one study showed that cyclic boronates $\mathbf{1 9}$ and 20 (Figure 5) can be considered as a dual-role inhibitor acting as analogues of the first tetrahedral 
intermediate common to these two classes in pathways of hydrolysis catalyzed by these enzymes as confirmed by an X-ray structure analysis of a cyclic boronate complexed with beta-lactamase CTX-M-15. This makes them able to inhibit the representatives of the various beta-lactamases classes including A71 ESBL, CTX-M-15, class C enzymes and two variants of Oxa hydrolyzing carbapenem Oxa-23 and Oxa-48. ${ }^{55}$

In 2014, Aspergillomarasmine A (AMA) 21, a polyamino acid naturally produced by the mold Aspergillus versicolor has been reported to inhibit NDM-1 and VIM antibiotic resistance carbapenemase proteins in bacteria and render those antibiotic-resistant bacteria susceptible to antibiotics. ${ }^{56-58}$ Thus, in a mouse model of NDM-1-positive K. pneumoniae infection, a single dose of the combination of meropenem (10 mg/kg of body weight) and AMA (30 mg/kg) led to $95 \%$ survival after 5 days post infection whereas the use of meropenem or AMA alone at the same concentrations resulted in $0 \%$ survival. ${ }^{56}$

Recently, the well-known Primaxin combination ${ }^{59}$ (imipenem/cilastatin 22) was improved by the addition of the diazabicyclooctane $\beta$-lactamase inhibitor, relebactam 23 (also known as MK-7655), due to an increase in the prevalence of bacterial infections caused by carbapenemase-producing organisms that inactivate imipenem. MK-7655 can inhibit the activity of ESBLs, KPC and AmpC $\beta$-lactamases against imipenem by irreversibly blocking their reactive site.

\section{Efflux pumps inhibitors}

Mechanisms of drug efflux contribute to the resistance of bacteria to many classes of chemotherapeutic agents. Drug efflux results from the activity of membrane carriers involved in a variety of physiological processes and are called 'efflux pumps' ${ }^{62,63}$ These pumps provide a protective role by expelling the antibiotic to the outside of the bacterial cell. ${ }^{62}$ Some are selective 
and only expel a specific substrate, whereas others are non-selective and carry out a wide range of structurally-diverse compounds (dyes, organic solvents, detergents...) as well as different classes of antibiotics. ${ }^{64}$ This last category of pump is of a major clinical interest since they can make a bacterial infection untreatable by the available antibiotics, conferring the phenotype of multidrug resistance, defined by resistance to at least three different classes of antibiotics. ${ }^{65,66}$ Thus, the design of molecules that oppose the action of these pumps by improving the entry of the antibiotic and preventing its expulsion outside the bacterial cell constitutes an interesting approach that opens the door to the restoration of the bacterial susceptibility.

In this context, combinatorial antibiotic therapy with small molecules that block the multi-drug efflux systems named the efflux pump inhibitors (EPI) appears to be a promising strategy to overcome multi-drug resistance (MDR) ${ }^{67}$ Overexpression of MDR-efflux pumps confer bacterial resistance to antibiotics either by intrinsic resistance to a specific antibiotic or to a whole family of antibiotics. Efflux pump inhibition allows the restoration of sensitivity of resistant bacterial strains to antibiotics and limits the emergence of new resistant mutants. ${ }^{64,68}$ Targeting of the efflux pumps is carried out in several ways including a) inhibition of the expression of the genes encoding these pumps, b) prevention of the assembly of the pump components at the membrane level, c) blockade of the membrane outlet duct or d) depletion of the energy necessary for pumps to operate. ${ }^{69}$ The development of efflux pump inhibitors must consider three crucial factors: the type of pathogenic bacteria to be targeted, the type of pump to be inhibited, and the nature of the antibiotic to potentiate. ${ }^{69}$ In addition, pharmacodynamic characteristics and kinetic parameters are also critical to ensuring the effectiveness of these inhibitors. Thus, an ideal inhibitor must meet the following requirements:

1. It must be specific for the bacterial target and ideally free from any pharmacological activity on eukaryotic cells. 
2. It must be able to reach a therapeutically effective concentration in serum and reach its target in vivo to address intracellular infections.

3. It must have maximum specificity and efficacy provided by a therapeutic index and an improved pharmacokinetic profile.

4. It must be devoid of antibacterial activity to lower the possibility of the development of resistance mechanisms.

5. And above all, it must be devoid of any toxic effect for humans, since it is going to be used at high concentrations. ${ }^{68,70,71}$

One of the difficulties in targeting these efflux pumps is related to the variety of physiological functions they can perform, which can cause unexpected toxicities when they are blocked. Therefore research is focused on finding compounds that specifically inhibit pumps operating only in prokaryotic cells. ${ }^{64}$ Given this need, a wide variety of studies have been performed to identify the substrates and inhibitors of these pumps, as well as for the implementation of efflux inhibition therapies (Figure 6, Table 2). It is noteworthy that to date no efflux pump inhibitors have been registered for the treatment of bacterial infections in human or veterinary clinics and the only documented inhibitor is currently MP-601.205 24 administered as an aerosol in patients with ventilator-associated pneumonia or cystic fibrosis. ${ }^{63,64}$

Quinoline derivatives have been tested as inhibitors of efflux pumps of E. Aerogenes MDR clinical strains expressing AcrAB efflux pumps conferring antibiotic resistance, piperidinoethyl branched side chain compound 7-Nitro-8-methyl-4-(2'-(piperidino) ethyl)-aminoquinoline 25 showed the highest inhibitory activity at the lowest concentration, and when used in combination with chloramphenicol, increased intracellular accumulation of chloramphenicol was observed. Concerning the observed inhibition of the pump a potent explanation is based on the Escherichia TolC structure showing an internal channel with a diameter of $35 \AA$ whereas the diameter of the 
alkylaminoquinolines is $20 \AA$ suggesting that the inhibition of the pump can occur either on the carrier of the inner membrane, or on the inner junction of the pump and the outer channel. ${ }^{72}$ Another study showed that Conessine 26, a natural steroidal alkaloid extracted from the Holarrhena antidysenteric plant, demonstrated an inhibitory activity of the MexABOprM or MexB efflux pumps overexpressed in $P$. aeruginosa. Furthermore, this compound allowed the reduction of the minimum inhibitory concentrations encountered of at least 8 times for all the antibiotics associated such as cefotaxime, erythromycin, levofloxacin, novobiocin, rifampicin, tetracycline. ${ }^{73}$ In a study that targets the inhibition of the archeatypical transporter AcrB of Escherichia coli, a series of compounds based on a 2-naphthamide core was designed and evaluated for its ability to potentiate antibiotic activity and to oppose the bacterial resistance conferred by the expression of AcrAB-TolC efflux pump. Thus, the compound 4-isopentyloxy-2-naphthamide 27 was the most effective in reducing the MIC of erythromycin and chloramphenicol in the threshold observed in susceptible bacterial strains not expressing efflux pumps. This compound can be considered as a specific inhibitor of the AcrB efflux pump, since it shows no effect on the MIC of rifampicin, which is not a AcrB substrate. ${ }^{74}$

In 2015, a 3.4-dibromopyrrole-2,5-dione compound $\mathbf{2 8}$ was identified from marine microbial extracts and was able to inhibit efflux pumps and enhance the activity of antibiotics such as ciprofloxacin, erythromycin and chloramphenicol against MDR Gram-negative bacterial strains. The inhibition was confirmed by its ability to cause a dose-dependent increase in fluorescence due to the accumulation of a fluorescent dye (Hoechst 33342) via the AcrAB-TolC efflux pump overexpressed in E. coli AG100 and by the non-assignment of H33342 fluorescence in the susceptible strain of E. coli AG100A devoid of RND pumps. This clearly shows that the RND pump is the target of this compound and that the restoration of sensitivity results from its inhibition. ${ }^{75}$ 
In Pseudomonas aeruginosa, the Mex-AB-OprM efflux pump is responsible for the observed multi-resistance. A polyphenolic compound, epigallocatechin-3-gallate (EGCG 29) extracted from tea, was investigated for its ability to inhibit this type of pump. It appears that this compound is able to increase antibiotic susceptibility of 22 multi-resistant $P$. aeruginosa clinical strains. ${ }^{76}$ For a better understanding of the effect of EGCG on bacterial susceptibility to antibiotics, FIC indexes were determined between EGCG and chloramphenicol (or tetracycline) suggesting that EGCG improves the sensitivity of $P$. aeruginosa clinical isolates to chloramphenicol and tetracycline in a synergistic manner. At the same time, PA $\beta \mathrm{N} 30$ was demonstrated to be a specific inhibitor of the MexAB-OprM efflux pump improving sensitivity of antibiotics to much higher levels than EGCG or PA $\beta \mathrm{N}$ taken alone. ${ }^{76}$

Currently, most of available antibiotics exert their action at the intracellular level, which requires their penetration inside the bacterial cell through the cell membrane. Gram-negative bacteria have an additional layer of protection represented by the outer membrane. ${ }^{77}$

For their penetration into the bacterium, the antibiotics follow two different pathways predominantly controlled by the chemical composition of the drug molecule:

Hydrophobic compounds (such as aminoglycosides, macrolides, rifampicin) diffuse through the lipid bilayer

Hydrophilic molecules (such as $\beta$-lactams, fluoroquinolones and phenicol antibiotics) diffuse through porins of the bacterium..$^{77,78}$

Thus, the composition of the membrane, the bacterial porins and membrane lipids all contribute to the membrane permeability and strongly impact the susceptibility of the bacterium towards the antibiotics. Therefore, it is not surprising that the emerging resistant strains often have lipid or membrane protein modifications. ${ }^{77}$ To date, a better understanding of the membrane structure plays 
a crucial role in the development of new classes of antibiotics ${ }^{79}$ and a new strategy consists in the design and use of compounds that could facilitate the diffusion of antibiotics and increase their intracellular concentration. ${ }^{80}$

In this context, several chemosensitizers that alter porins and membrane channels have been proposed such as detergents, surfactants, polymyxins, and antimicrobial peptides, as well as some cyclic lipopeptides polycationic and cationic antimicrobial peptides ${ }^{81,82}$ have been used in combination with antibiotics to control resistant strains. ${ }^{83,84}$

Another study aimed at evaluating the antibacterial activity of a glycine basic peptide (GBP) via its action on the membrane of E. Coli. This peptide showed a concentration--dependent antibacterial action against E. coli. ${ }^{85}$ The study of its effect on the morphology of E. Coli cells showed that it induces damage to these cells with morphological changes, leading to cells with wrinkled external structures and even arriving to GBP-induced fragmentations at a high concentration. This cationic peptide destroyed the membrane barrier and disrupted the E. coli ionchannel resulting in leakage of ions $\mathrm{Ca}^{2+}, \mathrm{K}^{+}$and $\mathrm{Mg}^{2+}$. This effect is generally observed in membrane-targeting peptides that cause cell death by the leakage of ions $\left(\mathrm{Ca}^{2+,} \mathrm{K}^{+}\right.$and $\left.\mathrm{Mg}^{2+}\right)$ or by affecting the surface tension of the membranes, or by disrupting existing ionic channels or causing the formation of new ones. ${ }^{85}$

Its effect on the permeability of the outer membrane improved the sensitivity of $E$. Coli at low concentrations of two hydrophobic antibiotics: erythromycin and rifampicin. These are unable to penetrate the intact membrane of Gram-negative bacteria, but they are capable of penetrating membranes damaged by polycations. These observations indicated that the GBP damages the outer membrane and increases its permeability. ${ }^{85}$

In this context, a study was carried out on the evaluation of menadione $\mathbf{3 1}$ (vitamin K) (Figure 7, Table 3) on the membrane permeability of multi-resistant strains of Staphylococcus aureus, 
Pseudomonas aeruginosa and Escherichia coli. Menadione is a soluble synthetic vitamin converted to vitamin $\mathrm{K} 2$ at the intestinal level. It showed antibacterial activity only against strains of $P$. aeruginosa but its use in combination with antibiotics from the aminoglycosides family allows the reduction of the inhibitory concentration of these antibiotics and suggested a synergistic action of this combination therapy. ${ }^{86}$

In 2014, a study was carried out on the ethanol extract of Holarrhena antidysenterica, a medicinal plant. The plant's bark is typically used in traditional medicine to treat dysentery, especially amoebic dysentery. ${ }^{87}$ Presenting only low antibacterial activity, this extract was successfully combined with novobiocin, a well-known antibiotic active against Gram-positive bacteria, allowing the improvement of its activity against XDRAB, MDRAB and non-MDRAB Gramnegative clinical isolates. ${ }^{87}$ This reversal of strain resistance to novobiocin was reported to be due to the extract's permeabilizing action on the outer-membrane.

Endogenous antimicrobial peptides (AMPs) secreted by epithelial cells, neutrophils, and exocrine glands represent an important defensive line in innate immunity against invasive pathogens. AMPs destabilize the outer membrane of prokaryotes following the formation of an amphipathic alpha or short beta sheet. ${ }^{88,89}$ These peptides represent new antibiotic molecules for their ability to induce non-specific membrane dysfunction and for the speed of their action. ${ }^{90,91}$ Nevertheless, their therapeutic use remains questionable mainly due to the prohibitive costs of their large-scale production as well as the development of mechanisms of resistance by the bacteria. Bacteriallysecreted proteases have been shown to neutralize AMPs' activity. ${ }^{92-94}$

To circumvent this problem and based on the advantageous properties of AMPs, a new class of Cationic Steroidal Antibiotics (CSA) named "Ceragenins" were designed where aminoalkyl groups substituted the alkoxy groups of the considered sterol (Figure 7, Table 3). ${ }^{95,96}$ Ceragenins are resistant to the action of proteases because they are not peptide-based and are easily produced in 
large amounts. Beyond that, they incorporate into membranes in a more stable manner and have an unusual ability to form complexes with phospholipids ${ }^{96,97}$ On the other hand, the positive charge of these cationic antimicrobial lipids ensures their electrostatic attraction to negatively charged membranes (bacteria, viruses, fungi and protozoa) and causes cell death through dysfunction of the membrane. ${ }^{97}$ Ceragenins 32-33 synthesized to mimic the cationic structures and amphiphilic properties of antimicrobial peptides, share with them the same mechanism of action. They induce a rapid depolarization of the bacterial membrane and permeabilize the outer membranes of Gramnegative bacteria, increasing the susceptibility of microorganisms to hydrophobic antibiotics. ${ }^{98-100}$ Thus, although the MIC of erythromycin used alone against a resistant strain of Klebsiella pneumoniae is $70 \mu \mathrm{g} / \mathrm{mL}$ its combination with compound CSA-8 (33) demonstrated that the concentration required for growth inhibition decreases to $1 \mu \mathrm{g} / \mathrm{mL} .^{92,95,101}$

CSA-13 (compound 32) in combination with gentamycin induces an early synergy against methicillin- and vancomycin-resistant S. aureus strains isolated from patients in the United States PA-VRSA and an early additivity with MI-VRSA. Additionally, an early additivity was observed against PA-VRSA in the case of the combinations of CSA-13 with daptomycin, linezolid and vancomycin. ${ }^{102}$ Furthermore, a study carried out on sixty carbapenem-resistant strains of $A$. baumannii reported a bactericidal activity of CSA-13 with similar and independent MICs. Nevertheless, by combining CSA-13 with antibiotics, synergy was achieved with colistin (55\%), and tobramycin $(35 \%)$ and no antagonism were observed. ${ }^{103}$

One study showed that naphthylacetylspermine $\mathbf{3 4}$, a synthetic analogue of joro-spider toxin and methoctramine (N, N' [6-[[(2-methoxyphenyl) methyl] amino] hexyl]-1,8-octanediamine), initially known as antagonist of muscarinic receptors, potentiated the action of hydrophobic antibiotics such as novobiocin and erythromycin. Compound $\mathbf{3 4}$ acts like a membrane permeabilizer and facilitates the diffusion of these antibiotics through the outer membrane of E. coli (Figure 8, Table 4).$^{104}$ 
These two polyamines were found to cause the release of divalent cations $\left(\mathrm{Ca}^{2+}\right)$ stabilizing the LPS and then stimulating the absorption of a lipophilic tetraphenylphosphonium salt, which is usually favored by outer membrane disruption. ${ }^{105}$

This mechanism of action is not specific to these two polyamines since other polycationic peptides such as polylysine and protamine $\mathrm{e}^{105,106}$ and antimicrobials such as chlorhexidine and polyhexamethylene biguanide ${ }^{107}$ have been reported to improve membrane permeability too.

Recently, new compounds isolated from the dogfish shark such as the water-soluble cationic aminosterol squalamine, was found to potentiate the activity of antibiotics by targeting the outer membrane of Gram-negative bacteria. Squalamine has demonstrated an interesting potent permeabilizing effect of the bacterial membrane of Gram-negative bacteria. ${ }^{108}$ In a first approach, the results suggested that this compound disrupted the membrane integrity leading to an exhaustion of $80 \%$ of intracellular ATP for a concentration of squalamine of $20 \mu \mathrm{g} / \mathrm{mL}$ (Figure 8, Table 4). ${ }^{108}$ More recently, its chemosensitizing action was evaluated by determining the MICs of antibiotics combined with sub-inhibitory concentrations of squalamine. Squalamine exerted a synergistic effect on all classes of antibiotics such as chloramphenicol, tetracycline and ciprofloxacin with a significant reduction in the MIC observed against strains with over-expressed efflux pumps. ${ }^{109}$ The potentiation of antibiotic activity against susceptible and resistant bacterial strains $(E$. Aerogenes, P. aeruginosa, E. coli, E. coli AG100, E. coli AG100a) suggested that the action exerted by squalamine is strongly linked to the diffusion of the antibiotic and not necessarily linked to a mechanism of resistance. This feature allows the chemosensitization of the membranes of the susceptible strains and therefore enables a reduction in antibiotic dose. All these results make squalamine an excellent candidate for combinations with antibiotics, especially those targeting the MDR bacteria. ${ }^{110}$ 
Recently, the design and biological evaluation of new polyaminosterol derivatives was reported. Thus, claramine A1 is the first member of a new family of compounds structurally analogous to squalamine exerting a bactericidal activity against a wide range of both Gram-positive and Gramnegatives bacteria, and even against those presenting a multiple antibiotic resistant profile (MDR) with MICs varying from 2 to $32 \mu \mathrm{g} / \mathrm{mL}$. Furthermore, as an adjuvant to antibiotics, it showed very good results. The compound allowed for the restoration of the antibacterial activity of doxycycline against $P$. aeruginosa PAO1 and E. aerogenes EA289 by reducing its MIC from 16 and $40 \mu \mathrm{g} / \mathrm{mL}$ to 2 and $0.5 \mu \mathrm{g} / \mathrm{mL}$, respectively. In addition, $4 \mu \mathrm{g} / \mathrm{mL}$ of claramine A1 was sufficient to restore the efficacy of chloramphenicol against P. aeruginosa PAO1 (Figure 8, Table 4). ${ }^{11}$

With the objective of developing chemosensitizers that can increase the efficacy of conventional antibiotics by improving membrane permeability, a study has focused on the evaluation of a series of polyamino motuporamine derivatives initially extracted from the marine sponge Xestospongia exigua. $^{112}$ Thus, combination therapies of these polyamine derivatives as adjuvant with doxycycline demonstrated that some of them were able to allow the restoration of the antibiotic activity against resistant E. aerogenes EA289, $P$. aeruginosa PAO1 and $K$. Pneumonia KPC2ST258 even at low concentrations $(2 \mu \mathrm{g} / \mathrm{mL})$. Several of them also reacted in synergy with chloramphenicol and erythromycin especially against PAO1 but at a lower level against EA289 and KPC2-ST258. ${ }^{112}$ The compounds $\mathbf{3 8}$ and $\mathbf{3 9}$ were the most effective as an adjuvant to doxycycline, during an ATP release assay. Thus, MOTU-N44 39 caused a disruption of the bacterial membrane affecting its permeability. Membrane depolarization which deenergizes the efflux pump was also observed leading to an increase of the activity of the associated antibiotic. ${ }^{110}$ Finally, the results of various tests concluded that the permeabilization of the bacterial membrane in E. aerogenes EA289 by motuporamine_derivatives was related to the change in the transmembrane electrical potential leading to altered proton homeostasis. ${ }^{112}$ 
In this same area, a series of ianthelliformisamines A, B, and C (40-42) were identified, synthesized and used to enhance Gram-negative bacteria susceptibility to hydrophobic antibiotics. ${ }^{113}$ Thus, natural and synthetic derivatives were used to restore the activity of doxycycline against Enterobacter aerogenes EA289, P. aeruginosa PAO1, and K. pneumoniae KPC2 ST258. On a mechanistic point of view, the absence of ATP efflux observed with the association of doxycycline and of the most efficient derivative $\mathbf{4 3}$ suggests that the integrity of the outer membrane of the bacteria is intact, whereas depolarization of the PAO1 membrane is consistent with a proton gradient disturbance.

Extending this approach to other hydrophobic substituents, polyamino-isoprenyl derivatives have been reported to reduce the resistance levels in multi-resistant enterobacteria towards nalidixic acid and chloramphenicol. ${ }^{114}$ Additionally, another study demonstrated that derivative 44, when used in combination with doxycycline, completely abolished bacterial growth with a Fractional Inhibitory Concentration (FIC) index of 0.09 . This result suggested a strong synergy exists between the considered antibiotic and the associated polyaminoisoprenyl chemosensitizing agent. Thus, compound 44 allows the reduction of resistance in MDR bacteria against two antibiotics belonging to two different families: doxycycline and chloramphenicol. ${ }^{115}$ Furthermore, this suggests that compound 44 can overcome the natural resistance of $P$. aeruginosa given its polyamino-farnesyl structure which facilitates the diffusion of the molecule through the external membrane of $P$. aeruginosa. This membrane is known for its high impermeability due to the presence of a highly hydrophobic double lipid layer. Moreover, the positively charged spermine group could interact with the negative charge of the external bacterial membrane leading to its perturbation and embrittlement. Finally, it was shown that compound $\mathbf{4 4}$ could inhibit $P$. aeruginosa efflux pumps by decreasing the proton gradient energy source. ${ }^{115}$ 


\section{Conclusion}

In summary, multiple approaches have been developed to combat bacterial resistance. In general, amphiphatic molecules like $\mathbf{3 9}$ and $\mathbf{4 3}$ provide the opportunity to target difficult-to-traverse bacterial membranes by providing both hydrophilic substituents (polyamines), which interact with negative charges present in the surface of the membrane as well as hydrophobic substituents which interact with and disrupt the organization of lipid chains in the bacterial membrane. This adjuvant design provides an opportunity to perform polypharmacy on bacteria by not only providing greater internal access to the co-dosed antibiotics but also by de-energizing the efflux pumps used by the bacteria to escape antibiotic action. In conclusion, the solution to emerging antibiotic resistance will likely involve combination therapies of existing antibiotics and smart adjuvants, which reempower the antibiotic agent to become efficacious against the resistant strain of interest.

\section{References}

(1) Wright, G. D. Molecular mechanisms of antibiotic resistance. Chem. Commun. 2011, 47, 40554061.

(2) Lin, J.; Nishino, N.; Roberts, M. C.; Tolmasky, M.; Aminov, R. I.; Zhang, L. Mechanisms of antibiotic resistance. Front. Microbiol. 2015, 6, 1-3.

(3) Džidić, S.; Šušković, J.; Kos, B. Antibiotic resistance mechanisms in bacteria: biochemical and genetic aspects. Food Technol. Biotechnol. 2008, 46, 11-21. 
(4) Nicaido, H.; Zgurskaya, H. Antibiotic efflux mechanism. Curr. Opin. Infect. Dis. 1999, 12, $529-536$.

(5) Webber, M.; Piddock, L. The importance of efflux pumps in bacterial antibiotic resistance. $J$. Antimicrob. Chemother. 2003, 51, 9-11.

(6) Van Veen, H.; Konings, W. Drug efflux proteins in multidrug resistant bacteria. Biol. Chem. 1997, 378, 769-777.

(7) Cox, G.; Wright, G. D. Intrinsic antibiotic resistance: mechanisms, origins, challenges and solutions. Int. J. Med. Microbiol. 2013, 303, 287-292.

(8) Piddock, L. J. Multidrug-resistance efflux pumps? not just for resistance. Nat. Rev. Microbiol. 2006, 4, 629-636.

(9) Paulsen, I. T.; Brown, M. H.; Skurray, R. A. Proton-dependent multidrug efflux systems. Microbiol. Rev. 1996, 60, 575-608.

(10) Wright, G. D. The antibiotic resistome: the nexus of chemical and genetic diversity. Nat. Rev. Microbiol. 2007, 5, 175-186.

(11) Mims, C.; Dockrell, H. M.; Goering, R. V.; Roitt, I.; Wakelin, D.; Zuckerman, M. Attacking the Enemy: Antimicrobial Agents and Chemotherapy: Macrolides," Medical Microbiology, 3rd Edition, Mosby Ltd, London, 2004, p. 489.

(12) Walsh, C. Molecular mechanisms that confer antibacterial drug resistance. Nature 2000, 406, 775-781.

(13) Kapoor, G.; Saigal, S.; Elongavan, A. Action and resistance mechanisms of antibiotics: A guide for clinicians. J. Anaesthesiol. Clin. Pharmacol. 2017, 33, 300-305.

(14) Philippon, A.; Arlet, G.; Jacoby, G. A. Plasmid-determined AmpC-type $\beta$-lactamases. Antimicrob. Agents Chemother. 2002, 46, 1-11. 
15 Bradford, P. A. Extended-spectrum $\beta$-lactamases in the 21st century: characterization, epidemiology and detection of this important resistance threat. Clin. Microbiol. Rev. 2001, $14,933-951$.

16 Shah, A.; Hasan, F.; Ahmed, S.; Hameed, A. Extended-spectrum $\beta$-lactamases (ESBLs): characterization, epidemiology and detection. Crit. Rev. Microbiol. 2004, 30, 25-32.

17 Giedraitienè, A.; Vitkauskienè, A.; Naginienė, R.; Pavilonis, A. Antibiotic resistance mechanisms of clinically important bacteria. Medicina 2011, 47, 137-146.

18 Alekshun, M. N.; Levy, S. B. Molecular mechanisms of antibacterial multidrug resistance. Cell 2007, 128, 1037-1050.

19 Greenwood, D. Antimicrobial chemotherapy. (Oxford university press, USA, 2007).

20 Khoder, M.; Tsapis, N.; Fattal, E. Mechanisms of antibiotic resistance and delivery strategies to prevent its emergence. J. Drug Deliv. Sci. Technol. 2010, 20, 407-418.

21 Alonso, A.; Campanario, E.; Martínez, J. L. Emergence of multidrug-resistant mutants is increased under antibiotic selective pressure in Pseudomonas aeruginosa. Microbiology 1999, 145, 2857-286.

22 Hawkey, P. M. The origins and molecular basis of antibiotic resistance. Br. Med. J. 1998, 317, 657-660.

23 Courvalin, P. Predictable and unpredictable evolution of antibiotic resistance. J. Intern. Med. 2008, 264, 4-16.

24 Levy, S. B.; Marshall, B. Antibacterial resistance worldwide: causes, challenges and responses. Nat. Med. 2004, 10, S122-S129.

25 Bennett, P. Plasmid encoded antibiotic resistance: acquisition and transfer of antibiotic resistance genes in bacteria. Br. J. Pharmacol. 2008, 153, S347-S357. 
26 Lyon, B. R.; Skurray, R. Antimicrobial resistance of Staphylococcus aureus: genetic basis. Microbiol. Rev. 1987, 51, 88-134.

27 Domalaon, R.; Idowu, T.; Zhanel, G. G.; Schweizer, F. Antibiotic hybrids: the next generation of agents and adjuvants against Gram-negative pathogens? Clin. Microbiol. Rev. 2018, 31, e00077-17.

28 Eliopoulos, G.; Eliopoulos, C. Antibiotic combinations: should they be tested? Clin. Microbiol. Rev. 1988, 1, 139-156.

29 Wright, G. D. Antibiotic adjuvants: rescuing antibiotics from resistance. Trends Microbiol. 2016, 24, 862-871.

30 Brooks, B. D.; Brooks, A. E. Therapeutic strategies to combat antibiotic resistance. Adv. Drug Del. Rev. 2014, 78, 14-27.

31 González-Bello, C. Antibiotic adjuvants-A strategy to unlock bacterial resistance to antibiotics. Bioorg. Med. Chem. Lett. 2017, 27, 4221-4228.

32 Kalan, L.; Wright, G. D. Antibiotic adjuvants: multicomponent anti-infective strategies. Expert Rev. Mol. Med. 2011, 13, e5.

33 Chakradhar, S. Reservoirs of resistance: To understand why antibiotics fail, geneticists chase the 'resistome'. Nat. Med. 2016, 22, 1069-1071.

34 Melander, R. J.; Melander, C. The challenge of overcoming antibiotic resistance: an adjuvant approach? ACS infectious diseases 2017, 3, 559-563.

35 Martins, M.; Dastigar, S. G.; Fanning, S.; Kristiansen, J. E.; Molnar, J.; Pagès, J. M.; Scheltz, Z.; Spengler, G.; Viveiros, M.; Amaral, L. Potential role of non-antibiotics (helper compounds) in the treatment of multidrug-resistant Gram-negative infections: mechanisms for their direct and indirect activities. Int. J. Antimicrob. Agents 2008, 31, 198-208. 
36 Kristiansen, J. E.; Amaral, L. The potential management of resistant infections with nonantibiotics. The Journal of antimicrobial chemotherapy 1997, 40, 319-327.

37 Amaral, L.; Lorian, V. Effects of chlorpromazine on the cell envelope proteins of Escherichia coli. Antimicrob. Agents Chemother. 1991, 35, 1923-1924.

38 Dutta, N. K.; Annadurai, S.; Mazumdar, K.; Dastidar, S. G.; Kristiansen, J. E.; Molnar, J.; Martins, M.; Amaral, L. Potential management of resistant microbial infections with a novel non-antibiotic: the anti-inflammatory drug diclofenac sodium. Int. J. Antimicrob. Agents 30, 242-249 (2007).

39 Amaral, L.; Martins, M.; Viveiros, M. Enhanced killing of intracellular multidrug-resistant Mycobacterium tuberculosis by compounds that affect the activity of efflux pumps. $J$. Antimicrob. Chemother. 2007, 59, 1237-1246.

40 Bush, K. Beta-lactamase inhibitors from laboratory to clinic. Clin. Microbiol. Rev. 1988, 1 , 109-123.

41 Page, M. G. $\beta$-Lactamase inhibitors. Drug Resistance Updates 2000, 3, 109-125.

42 Williams, J. D. $\beta$-Lactamase inhibition and in vitro activity of sulbactam and sulbactam/cefoperazone. Clin. Infect. Dis. 1997, 24, 494-497.

43 Shlaes, D. M. New $\beta$-lactam- $\beta$-lactamase inhibitor combinations in clinical development. Ann. N.Y. Acad. Sci. 2013, 1277, 105-114.

44 White, A. R.; Kaye, C.; Poupard, J.; Pypstra, R.; Woodnutt, G.; Wynne, B. Augmentin (amoxicillin/clavulanate) in the treatment of communityacquired respiratory tract infection: a review of the continuing development of an innovative antimicrobial agent. J. Antimicrob. Chemother. 2004, 53, i3-i20. 
45 Drawz, S. M.; Bonomo, R. A. Three decades of beta-lactamase inhibitors. Clin. Microbiol. Rev. 2010, 23, 160-201.

46 Gniadkowski, M. Evolution and epidemiology of extendedspectrum beta-lactamases (ESBLs) and ESBL-producing microorganisms. Clin. Microbiol. Infect. 2001, 7, 597-608.

47 Paterson D. L.; Bonomo, R. A. Extended-spectrum beta-lactamases: a clinical update. Clin. Microbiol. Rev. 2005, 18, 657-686.

48 Wright, G. D. Antibiotic adjuvants: rescuing antibiotics from resistance. Trends Microbiol. 2016, $24,862-871$.

49 Gill, E. E., Franco, O. L., Hancock, R. E. W. Antibiotic adjuvants: diverse strategies for controlling drug-resistant pathogens. Chem. Biol. Drug Des. 2015, 85, 56-78.

50 Pieren, M.; Tigges, M. Adjuvant strategies for potentiation of antibiotics to overcome antimicrobial resistance. Curr. Opin. Pharmacol. 2012, 12, 551-555.

51 Kalan, L.; Wright, G. D. Antibiotic adjuvants: multicomponent antiinfective strategies. Expert Rev. Mol. Med. 2011, 13, e5.

52 Yenn, T. W.; Arslan Khan, M.; Amiera Syuhada, N.; Chean Ring, L.; Ibrahim, D.; Tan, W. N. Stigmasterol: An adjuvant for beta lactam antibiotics against beta-lactamase positive clinical isolates. Steroids 2017, 128, 68-71.

53 English, A. R.; Retsema, J. A.; Girard, A. E.; Lynch, J. E.; Barth, W. E. CP-45,899, a betalactamase inhibitor that extends the antibacterial spectrum of beta-lactams: initial bacteriological characterization. Antimicrob. Agents Chemother. 1978, 14, 414-419.

54 Bonnefoy, A.;Dupuis Hamelin, C.; Steier, V.; Delachaume, C.; Seys, T.; Stachyra, M.; Fairley, M.; Guitton, M.; Lampilas, M. In vitro activity of AVE1330A, an innovative broad- 
spectrum non- $\beta$-lactam $\beta$-lactamase inhibitor. J. Antimicrob. Chemother. 2004, 54, 410417.

55 Cahill, S. T.; Cain, R.; Wang, D. Y.; Lohans, C. T.; Wareham, D. W.; Oswin, H. P.; Mohammed, J.; Spencer, J.; Fishwick, C. W. G.; McDonough, M. A.; Schofield, C. J.; Brem, J.. Cyclic boronates inhibit all classes of $\beta$-lactamases. Antimicrob. Agents Chemother. 2017, 61, e02260-02216.

56 King, A. M.; Reid-Yu, S. A.; Wang, W.; King, D. T.; De Pascale, G.; Strynadka, N. C.; Walsh, T. R.; Coombes, B. K.; Wright, G. D. Aspergillomarasmine A overcomes metallobeta-lactamase antibiotic resistance. Nature 2014, 510, 503-506.

57 Koteva, K.; King, A. M.; Capretta, A.; Wright, G. D. Total synthesis and activity of the metallo-beta-lactamase inhibitor aspergillomarasmine A. Angew. Chem. Int. Ed. Engl. 2016, 55, $2210-2212$.

58 Albu, S. A.; Koveta, K.; King, A. M.; Al-Karmi, S.; Wright, G. D.; Capretta, A. Total synthesis of aspergillomarasmine A and related compounds: a sulfamidate approach enables exploration of structure-activity relationships. Angew. Chem. Int. Ed. Engl. 2016, $55,13259-13262$.

59 Jacobs, R. F. Imipenem-cilastatin: the first thienamycin antibiotic. Pediatr. Infect. Dis. 1986, 5, 444-448.

60 von Nussbaum, F.; Schiffer, G. Aspergillomarasmine A, an Inhibitor of Bacterial Metallo$\beta$-Lactamases Conferring blaNDM and blaVIM Resistance. Angew. Chem. Int. Ed. Engl. 2014, 53, 11696-11698.

61 Blizzard, T. A.; Chen, H.; Kim, S.; Wu, J.; Bodner, R.; Gude, C.; Imbriglio, J.; Young, K.; Park, Y. W.; Ogawa, A.; Raghoobar, S.; Hairston, N.; Painter, R. E.; Wisniewski, D.; Scapin, G.; Fitzgerald, P.; Sharma, N.; Lu, J.; Ha, S.; Hermes, J.; Hammond, M. L. 
Discovery of MK-7655, a $\beta$-lactamase inhibitor for combination with Primaxin ${ }^{\text {. Bioorg. }}$ Med. Chem. Lett. 2014, 24, 780-785.

62 Van Bambeke, F.; Glupczynski, Y.; Plesiat, P.; Pechere, J. ; Tulkens, P. M. Antibiotic efflux pumps in prokaryotic cells: occurrence, impact on resistance and strategies for the future of antimicrobial therapy. J. Antimicrob. Chemother. 2003, 51, 1055-1065.

63 P Tegos, G.; Haynes, M.; Strousse, J. J.; Khan, M. M.; Bologa, C. G.; Oprea, T. I. Sklar, L. A. Microbial efflux pump inhibition: tactics and strategies. Curr. Pharm. Des. 2011, 17, 1291-1302.

64 Zechini, B.; Versace, I. Inhibitors of multidrug resistant efflux systems in bacteria. Recent Pat. Antiinfect Drug Discov. 2009, 4, 37-50.

65 Li, X. Z.; Nikaido, H. Efflux-mediated drug resistance in bacteria. Drugs 2004, 64, 159204.

66 Poole, K. Efflux-mediated antimicrobial resistance. J. Antimicrob. Chemother. 2005, 56, $20-51$.

(67) Fiamegos, Y. C.; Kastritis, P. L.; Exarchou, V.; Han, H.; Bonvin, A. M. J. J.; Vervoot, J.; Lewis, K.; Hamblin, M. R.; Tegos, G. P. Antimicrobial and efflux pump inhibitory activity of caffeoylquinic acids from Artemisia absinthium against gram-positive pathogenic bacteria. PLoS One 2011, 6, e18127.

68 K Bhardwaj, A.; Mohanty, P. Bacterial efflux pumps involved in multidrug resistance and their inhibitors: rejuvinating the antimicrobial chemotherapy. Recent Pat. Antiinfect Drug Discov. 2012, 7, 73-89.

69 Bolla, J. M.; Alibert-Franco, S.; Handzlik, J.; Chevalier, J.; Mahamoud, A.; Boyer, G.; Kiec-Kononowicz, K.; Pagès, J. M. Strategies for bypassing the membrane barrier in multidrug resistant Gram-negative bacteria., FEBS Lett. 2011, 585, 1682-1690. 
70 Van Bambeke, F.; Lee, V. J. Inhibitors of bacterial efflux pumps as adjuvants in antibiotic treatments and diagnostic tools for detection of resistance by efflux. Recent Pat. Antiinfect Drug Discov. 2006, 1, 157-175.

71 Piddock, L. J. Clinically relevant chromosomally encoded multidrug resistance efflux pumps in bacteria. Clin. Microbiol. Rev. 2006, 19, 382-402.

72 Malléa, M.; Mahamoud, A.; Chevalier, J.; Alibert-Franco, S.; Brouant, P.; Barbe, J.; Pagès, J. M. Alkylaminoquinolines inhibit the bacterial antibiotic efflux pump in multidrugresistant clinical isolates. Biochem. J. 2003, 376, 801-805.

73 Siriyong, T.; Srimanote, P.; Chusri, S.; Yingyongnarongkul, B. E.; Suaisom, C. Tipmanee, V.; Voravuthikunchai, S. P. Conessine as a novel inhibitor of multidrug efflux pump systems in Pseudomonas aeruginosa. BMC Complement. Altern. Med. 2017, 17, 405.

74 Wang, Y.; Mowla, R.; Guo, L.; Ogunniyi, A. D.; Rahman, T.; De Barros Lopes, M. A.; Ma, S.; Venter, H. Evaluation of a series of 2-napthamide derivatives as inhibitors of the drug efflux pump AcrB for the reversal of antimicrobial resistance. Bioorg. Med. Chem. Lett. 2017, 27, 733-739.

75 Whalen, K. E.; Poulson-Ellestad, K. L.; Deering, R. W.; Rowley, D. C.; Mincer, T. J. Enhancement of antibiotic activity against multidrug-resistant bacteria by the efflux pump inhibitor 3, 4-dibromopyrrole-2, 5-dione isolated from a Pseudoalteromonas sp. J. Nat. Prod. 2015, 78, 402-412.

76 Kanagaratnam, R.; Sheikh, R.; Alharbi, F.; Kwon, D. H. An efflux pump (MexAB-OprM) of Pseudomonas aeruginosa is associated with antibacterial activity of Epigallocatechin-3gallate (EGCG). Phytomedicine 2017, 36, 194-200.

77 Delcour, A. H. Outer membrane permeability and antibiotic resistance. Biochim. Biophys. Acta 2009, 1794, 808-816. 
78 Nikaido, H. Molecular basis of bacterial outer membrane permeability revisited. Microbiol. Mol. Biol. Rev. 2003, 67, 593-656.

79 Zahn, M.; Bhamidimarri, S. P.; Baslé, A.; Winterhalter, M.; van den Berg, B. Structural insights into outer membrane permeability of Acinetobacter baumannii. Structure 2016, 24, 221-231.

80 Bolla, J. M.; Alibert-Franco, S.; Handzlik, J.; Chevalier, J.; Mahamoud, A.; Boyer, G.; Kiec-Kononowicz, K.; Pagès, J. M. Strategies for bypassing the membrane barrier in multidrug resistant Gram-negative bacteria., FEBS Lett. 2011, 585, 1682-1690.

81 Hurdle, J. G.; O'neill, A. J.; Chopra, I.; Lee, R. E. Targeting bacterial membrane function: an underexploited mechanism for treating persistent infections. Nat. Rev. Microbiol. 2011, $9,62-75$.

82 Vooturi, S.; Firestine, S. Synthetic membrane-targeted antibiotics. Curr. Med. Chem. 2010, 17, 2292-2300.

83 Falagas, M. E.; Rafailidis, P. I.; Matthaiou, D. K. Resistance to polymyxins: mechanisms, frequency and treatment options. Drug resistance updates 2010, 13, 132-138.

84 Vaara, M. Polymyxins and their novel derivatives. Curr. Opin. Microbiol. 2010, 13, 574581.

85 Li, Y.-Q.; Sun, X.-X.; Feng, J.-L.; Mo, H.-Z. Antibacterial activities and membrane permeability actions of glycinin basic peptide against Escherichia coli. Innov. Food Sci. Emerg. Technol. 2015, 31, 170-176.

86 Andrade, J. C.; Morais Braga, M. F.; Guedes, G. M.; Tintino, S. R.; Freitas, M. A.; Quintans, L. J. Jr; Menezes, I. R.; Coutinho, H. D. Menadione (vitamin K) enhances the antibiotic activity of drugs by cell membrane permeabilization mechanism. Saudi J. Biol. Sci. 2017, 24, 59-64. 
87 Chusri, S.; Na-Phatthalung, P.; Siriyong, T.; Paosen, S.; Voravuthikunchai, S. P. Holarrhena antidysenterica as a resistance modifying agent against Acinetobacter baumannii: its effects on bacterial outer membrane permeability and efflux pumps. Microbiol. Res. 2014, 169, 417-424.

88 Guaní-Guerra, E.; Santos-Mendoza, T.; Lugo-Reyes, S. O.; Terán, L. M. Antimicrobial peptides: general overview and clinical implications in human health and disease. Clin. Immunol. 2010, 135, 1-11.

89 Seil, M.; Nagant, C.; Dehaye, J.-P.; Vandenbranden, M.; Lensink, M. F. Spotlight on human LL-37, an immunomodulatory peptide with promising cell-penetrating properties. Pharmaceuticals 2010, 3, 3435-3460.

90 Ding, B.; Taotofa, U.; Orsak, T.; Chadwell, M.; Savage, P. B. Synthesis and Characterization of Peptide- Cationic Steroid Antibiotic Conjugates. Org. Lett. 2004, 6, 3433-3436.

91 Van Bambeke, F.; Mingeot-Leclercq, M.-P.; Struelens, M. J.; Tulkens, P. M. The bacterial envelope as a target for novel anti-MRSA antibiotics. Trends Pharmacol. Sci. 2008, 29, 124-134.

92 Lai, X.-Z.; Feng, Y.; Pollard, J.; Chin, J. N.; Rybak, M. J.; Bucki, R.; Epand, R. F.; Epand, R. M.; Savage, P. B. Ceragenins: cholic acid-based mimics of antimicrobial peptides. Acc. Chem. Res. 2008, 41, 1233-1240.

93 Jenssen, H.; Hamill, P.; Hancock, R. E. Peptide antimicrobial agents. Clin. Microbiol. Rev. 2006, 19, 491-511.

94 Bals, R.; Wilson, J. Cathelicidins-a family of multifunctional antimicrobial peptides. Cell. Mol. Life Sci. 2003, 60, 711-720. 
95 Li, C.; Peters, A. S.; Meredith, E. L.; Allman, G. W.; Savage, P. B. Design and synthesis of potent sensitizers of Gram-negative bacteria based on a cholic acid scaffolding. J. Am. Chem. Soc. 1998, 120, 2961-2962.

96 Epand, R. M.; Epand, R. F.; Savage, P. B. Ceragenins (cationic steroid compounds), a novel class of antimicrobial agents. Drug News Perspect 2008, 21, 307-311.

97 Surel, U.; Niemirowicz, K.; Marzec, M.; Savage, P. B.; Bucki, R. Ceragenins-a new weapon to fight multidrug resistant bacterial infections. Medical Studies 2014, 30, 207-213.

98 Ding, B.; Guan, Q.; Walsh, J. P.; Boswell, S.; Winter, T. W.; Winter, E. S.; Boydd, S. S.; Li, C.; Savage, P. B. Correlation of the antibacterial activities of cationic peptide antibiotics and cationic steroid antibiotics. J. Med. Chem. 2002, 45, 663-669.

99 Kikuchi, K.; Bernard, E. M.; Sadownik, A.; Regen, S. L.; Armstrong, D. Antimicrobial activities of squalamine mimics. Antimicrob. Agents Chemother. 1997, 41, 1433-1438.

100 Li, C.; Lewis, M. R.; Gilbert, A. B.; Noel, M. D.; Scoville, D. H.; Allman, G. W.; Savage, P. B. Antimicrobial activities of amine-and guanidine-functionalized cholic acid derivatives. Antimicrob. Agents Chemother. 1999, 43, 1347-1349.

101 Li, C.; Budge, L. P.; Driscoll, C. D.; Willardson, B. M.; Allman, G. W.; Savage, P. B. Incremental conversion of outer-membrane permeabilizers into potent antibiotics for Gramnegative bacteria. J. Am. Chem. Soc. 1999, 121, 931-940.

102 Chin, J. N.; Rybak, M. J.; Cheung, C. M.; Savage, P. B. Antimicrobial activities of ceragenins against clinical isolates of resistant Staphylococcus aureus. Antimicrob. Agents Chemother. 2007, 51, 1268-1273.

103 Bozkurt-Guzel, C.; Savage, P. B.; Akcali, A.; Ozbek-Celik, B. Potential synergy activity of the novel ceragenin, CSA-13, against carbapenem-resistant Acinetobacter baumannii strains isolated from bacteremia patients. BioMed Res. Int. 2014, 2014, 710273. 
104 Yasuda, K.; Ohmizo, C.; Katsu, T. Mode of action of novel polyamines increasing the permeability of bacterial outer membrane. Int. J. Antimicrob. Agents 2004, 24, 67-71.

105 Katsu, T.; Nakagawa, H.; Yasuda, K. Interaction between polyamines and bacterial outer membranes as investigated with ion-selective electrodes. Antimicrob. Agents Chemother. 2002, 46, 1073-1079.

106 Vaara, M. Agents that increase the permeability of the outer membrane. Microbiol. Rev. 1992, 56, 395-411.

107 Nikaido, H. "Outer membrane." Escherichia coli and Salmonella. Cell. Mol. Biol., 1996, $29-47$.

108 Yasuda, K.; Ohmizo, C.; Katsu, T. Potassium and tetraphenylphosphonium ion-selective electrodes for monitoring changes in the permeability of bacterial outer and cytoplasmic membranes. J. Microbiol. Methods 2003, 54, 111-115.

109 Salmi, C.; Loncle, C.; Vidal, N.; Letourneux, Y.; Fantini, J.; Maresca, M.; Taieb, N.; Pagès, J. M.; Brunel, J. M. et al. Squalamine: an appropriate strategy against the emergence of multidrug resistant gram-negative bacteria? PLoS One 2008, 3, e2765.

110 Lavigne, J.-P.; Brunel, J. M.; Chevalier, J.; Pagès, J. M. Squalamine, an original chemosensitizer to combat antibiotic-resistant gram-negative bacteria. J. Antimicrob. Chemother. 2010, 65, 799-801.

111 Blanchet, M.; Borselli, D.; Rodallec, A.; Peiretti, F.; Vidal, N.; Bolla, J. M.; Digiorgio, C.; Morrison, K. R.; Wuest, W. M.; Brunel, J. M. Claramines: A new class of broad-spectrum antimicrobial agents with bimodal activity. ChemMedChem 2018, 13, 1018-1027.

112 Borselli, D.; Blanchet, M.; Bolla, J. M.; Muth, A.; Skruber, K.; Phanstiel, O.; Brunel, J. M. Motuporamine Derivatives as Antimicrobial Agents and Antibiotic Enhancers against Resistant Gram-Negative Bacteria. ChemBioChem 2017, 18, 276-283. 
113 Pieri, C.; Borselli, D.; Di Giorgio, C.; De Méo, M.; Bolla, J. M.; Vidal, N.; Combes, S.; Brunel, J. M. New Ianthelliformisamine derivatives as antibiotic enhancers against resistant Gram-negative bacteria. J. Med. Chem. 2014, 57, 4263-4272.

114 Brunel, J. M.; Lieutaud, A.; Lome, V.; Pagès, J. M.; Bolla, J.-M. Polyamino geranic derivatives as new chemosensitizers to combat antibiotic resistant Gram-negative bacteria. Biorg. Med. Chem. 2013, 21, 1174-1179.

115 Borselli, D.; Lieutaud, A.; Thefenne, H.; Garnotel, E.; Pagès, J. M.; Brunel, J. M.; Bolla, J. M. Polyamino-isoprenic derivatives block intrinsic resistance of $\mathrm{P}$. aeruginosa to doxycycline and chloramphenicol in vitro. PLoS One 2016, 11, e0154490. 


\begin{tabular}{|c|c|c|c|c|c|c|}
\hline Adjuvant ${ }^{\text {Ref }}$ & Bacterial strain & $\begin{array}{l}\text { Enhanced } \\
\text { antibiotic }\end{array}$ & $\beta$-lactamase & $\mathrm{MIC}^{\mathbf{a}}$ & $\mathrm{MIC}^{\mathrm{b}}(\mathrm{AD}$ & \\
\hline $16^{52}$ & $\begin{array}{c}\text { S. aureus } \\
\text { S. pyogenes } \\
\text { E. coli } \\
\text { P. aeruginosa }\end{array}$ & AMP & ND & $\begin{array}{l}>200 \\
>200 \\
100 \\
>200\end{array}$ & $\begin{array}{l}3.13(\mathrm{ND}) \\
1.56(\mathrm{ND}) \\
6.25(\mathrm{ND}) \\
6.25(\mathrm{ND})\end{array}$ & 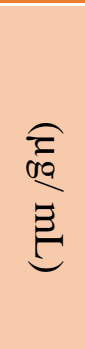 \\
\hline $17^{53}$ & $\begin{array}{c}\text { S. aureus } 01 A 400 \\
\text { S. epidermidis } 01 B 116 \\
\text { H. influenzae } 54 A 042 \\
\text { B. fragilis } 78 C 004\end{array}$ & PENI G & $\begin{array}{l}\text { Penicillinase } \\
\text { N.D } \\
\text { N.D } \\
\text { N.D }\end{array}$ & $\begin{array}{l}200 \\
>25 \\
200 \\
200\end{array}$ & $\begin{array}{l}1.56(3.12) \\
1.56(3.12) \\
1.56(1.56) \\
3.12(0.78)\end{array}$ & 曐 \\
\hline $18^{54}$ & $\begin{array}{c}\text { E. coli GN5482 } \\
\text { K. pneumoniae IP1 } \\
\text { K. pneumoniae } 25637 \\
\text { E. coli CF3 } \\
\text { K. pneumoniae IP86 } \\
\text { E. coli KB10 }\end{array}$ & CAZ & $\begin{array}{l}\text { TEM-1 (A) } \\
\text { TEM-2 (A) } \\
\text { TEM-4 (A) } \\
\text { TEM-8 (A) } \\
\text { SHV-2 (A) } \\
\text { PER-1 (A) }\end{array}$ & $\begin{array}{l}4 \\
16 \\
32 \\
64 \\
64 \\
>64\end{array}$ & $\begin{array}{r}0.5 \text { (ND) } \\
0.5(\mathrm{ND}) \\
0.5(\mathrm{ND}) \\
2(\mathrm{ND}) \\
1(\mathrm{ND}) \\
4(\mathrm{ND})\end{array}$ & 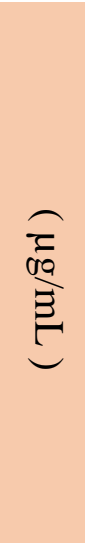 \\
\hline $20^{55}$ & E. coli (EC113) ST & $\begin{array}{l}\text { AMP } \\
\text { PIP } \\
\text { AZT } \\
\text { FAZ } \\
\text { CRO } \\
\text { CAZ } \\
\text { FEP }\end{array}$ & $\begin{array}{c}\text { CTX-M-27 } \\
\text { (A) }\end{array}$ & $\begin{array}{l}>16 \\
>64 \\
>16 \\
>16 \\
>32 \\
8 \\
>32\end{array}$ & $\begin{array}{r}\leq 8(10) \\
\leq 16(10) \\
\leq 1(10) \\
\quad 4(10) \\
<0.5(10) \\
\leq 1(10) \\
\leq 4(10)\end{array}$ & $\stackrel{00}{\stackrel{00}{3}}$ \\
\hline
\end{tabular}




\begin{tabular}{|c|c|c|c|c|c|}
\hline $21^{60}$ & $\begin{array}{c}\text { K. pneumoniae N11- } \\
2218\end{array}$ & MEM & NDM-1 (B) & 32 & $1(8)$ \\
\hline $23^{61}$ & $\begin{array}{l}\text { K. pneumoniae } \\
\text { P. aeruginosa }\end{array}$ & IMP & $\begin{array}{c}\mathrm{KPC}-2(\mathrm{~A}) \\
\mathrm{AmpC}\end{array}$ & $\begin{array}{l}\text { ND } \\
\text { ND }\end{array}$ & $\begin{array}{l}4(12.5 \mu \mathrm{M}) \\
4(4.7 \mu \mathrm{M})\end{array}$ \\
\hline
\end{tabular}

${ }^{\mathrm{a}} \mathrm{MIC}$ of the antibiotic alone; ${ }^{\mathrm{M}} \mathrm{MIC}$ of the antibiotic in the presence of the adjuvant at the requested concentration $(\mu \mathrm{g} / \mathrm{mL}$ in parentheses); AMP: ampicillin; PENI G: Benzylpenicillin; CAZ: ceftazidime; PIP: piperacillin; AZT: aztreonam; FAZ: cefazolin; CRO: ceftriaxone; FEP : cefepime ; IMP: imipenem; MEM: meropenem; ND: not determined.

Table1. Mics of antibiotics in the presence of adjuvants 16-23 against Gram-negative bacteria 


\begin{tabular}{|c|c|c|c|c|c|c|}
\hline Adjuvant Ref & $\begin{array}{c}\text { Bacterial } \\
\text { strain }\end{array}$ & $\begin{array}{l}\text { Targeted efflux } \\
\text { pump }\end{array}$ & Antibiotic & $\mathrm{MIC}^{\mathbf{a}}$ & \multicolumn{2}{|c|}{$\begin{array}{l}\operatorname{MIC}^{\mathrm{b}}(\mathrm{ADJ}) \\
(\mu \mathrm{g} / \mathrm{mL})\end{array}$} \\
\hline $25^{72}$ & $\begin{array}{c}\text { E. aerogenes } \\
\text { EA3 }\end{array}$ & AcrAB-TolC & $\begin{array}{l}\text { NOR } \\
\text { TET } \\
\text { CHL }\end{array}$ & $\begin{array}{ll}256 & 1 \\
8 & 0 . \\
512 & \end{array}$ & $\begin{array}{l}16(0.2 \mathrm{mM}) \\
.5(0.2 \mathrm{mM}) \\
2(0.2 \mathrm{mM})\end{array}$ & 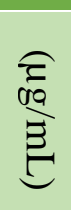 \\
\hline $26^{73}$ & $\begin{array}{c}\text { P. aeruginosa } \\
\text { K1455 (PAO1- } \\
\text { nal } \beta \text { ) }\end{array}$ & MexAB-OprM & $\begin{array}{l}\text { CTX } \\
\text { ERY } \\
\text { LEV } \\
\text { NOV } \\
\text { RIF } \\
\text { TET }\end{array}$ & $\begin{array}{l}64 \\
256 \\
2 \\
>2048 \\
16 \\
64\end{array}$ & $\begin{array}{r}8(20) \\
32(20) \\
0.25(20) \\
8 \quad 256(20) \\
2(20) \\
8(20)\end{array}$ & 曐 \\
\hline $27^{74}$ & E. coli & AcrAB-TolC & $\begin{array}{l}\text { ERY } \\
\text { CHL }\end{array}$ & $\begin{array}{l}128 \\
8\end{array}$ & $\begin{array}{r}16(256) \\
2(256)\end{array}$ & 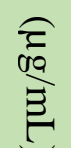 \\
\hline $28^{75}$ & E. coli AG102 & AcrAB-TolC & $\begin{array}{l}\text { CHL } \\
\text { CIP } \\
\text { ERY } \\
\text { KAN } \\
\text { LEV } \\
\text { OXA } \\
\text { PIP } \\
\text { TET }\end{array}$ & $\begin{array}{l}24 \\
0.13 \\
128 \\
16 \\
0.13 \\
>650 \\
4 \\
8\end{array}$ & $\begin{array}{r}6(64) \\
0.06(2) \\
16(128) \\
4(2) \\
0.03(128) \\
650(32) \\
2(32) \\
2(64)\end{array}$ & \\
\hline $29^{76}$ & $\begin{array}{c}\text { P. aeruginosa } \\
\text { PAO1 }\end{array}$ & Mex-AB-OprM & $\begin{array}{c}\text { CBN } \\
\text { CHL } \\
\text { CIP } \\
\text { NOV } \\
\text { TET } \\
\text { TRM }\end{array}$ & $\begin{array}{l}64 \\
64 \\
1 \\
512 \\
8 \\
128\end{array}$ & $\begin{array}{r}64(128) \\
16(128) \\
0.5(128) \\
128(128) \\
2(128) \\
32(128)\end{array}$ & 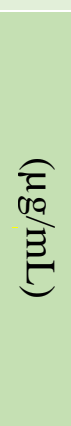 \\
\hline
\end{tabular}

${ }^{\mathrm{a}} \mathrm{MIC}$ of the antibiotic alone; ${ }^{\mathrm{b}} \mathrm{MIC}$ of the antibiotic in the presence of the adjuvant at the requested concentration $(\mu \mathrm{g} / \mathrm{mL}$ in parentheses); NOR: Norfloxacin; TET: Tetracycline; CHL: Chloramphenicol; CTX: Cefotaxime; Ery: Erythromycin; LEV: Levofloxacin; NOV: Novobiocin; RIF: Rifampicin; CIP: Ciprofloxacin; KAN: Kanamycin; OXA: Oxacillin; PIP: Piperacillin; CBN: Carbenicillin ; TRM: Trimethoprim; ND: not determined.

Table 2. MIC of antibiotics in the presence of adjuvants 25-29 against E. aerogenes, E. coli and $P$. aeruginosa strains 


\begin{tabular}{|c|c|c|c|c|c|}
\hline Adjuvant Ref & Bacterial strain & Antibiotic & $\mathrm{MIC}^{\mathbf{a}}$ & \multicolumn{2}{|c|}{$\mathrm{MIC}^{\mathrm{b}}(\mathrm{ADJ})$} \\
\hline $\mathbf{3 1}^{86}$ & $\begin{array}{l}\text { S. aureus } 358 \\
\text { P. aeruginosa } 03 \\
\text { E. coli } 27\end{array}$ & $\begin{array}{l}\text { AMI } \\
\text { GEN } \\
\text { NEO } \\
\text { AMI } \\
\text { GEN } \\
\text { NEO } \\
\\
\text { AMI } \\
\text { GEN } \\
\text { NEO }\end{array}$ & $\begin{array}{l}156.2 \\
312.5 \\
156.2 \\
\\
312.5 \\
625 \\
78.1 \\
\\
156.2 \\
625 \\
312.5\end{array}$ & $\begin{array}{l}2.4(64) \\
2.4(64) \\
2.4(64) \\
2.4(32) \\
2.4(32) \\
2.4(32) \\
2.4(64) \\
2.4(64) \\
2.4(64)\end{array}$ & 衰 \\
\hline $32^{102}$ & $\begin{array}{c}\text { E. coli ATCC } 10798 \\
P . \text { aeruginosa ATCC } 27853\end{array}$ & $\begin{array}{l}\text { ERY } \\
\text { NOV } \\
\text { NOV }\end{array}$ & $\begin{array}{l}70 \\
>500 \\
70\end{array}$ & $\begin{array}{r}1(1.5) \\
1(0.8) \\
1(2)\end{array}$ & 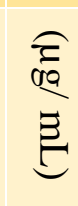 \\
\hline $33^{102}$ & $\begin{array}{c}\text { E. coli ATCC } 10798 \\
\text { P. aeruginosa ATCC } 27853\end{array}$ & $\begin{array}{l}\text { ERY } \\
\text { NOV } \\
\text { NOV }\end{array}$ & $\begin{array}{l}70 \\
>500 \\
70\end{array}$ & $\begin{array}{r}1(5) \\
1(14) \\
1(13)\end{array}$ & 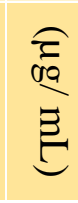 \\
\hline
\end{tabular}

${ }^{\mathrm{a}} \mathrm{MIC}$ of the antibiotic alone; ${ }^{\mathrm{b}} \mathrm{MIC}$ of the antibiotic in the presence of the adjuvant at the requested concentration ( $\mu \mathrm{g} / \mathrm{mL}$ in parentheses); AMI: Amikacin; GEN: Gentamicin; NEO: Neomycin; ERY: Erythromycin; NOV: Novobiocin.

Table 3. MIC of antibiotics in the presence of adjuvants 31-33 against E. coli and P. aeruginosa strains 



\begin{tabular}{|c|c|c|c|c|c|}
\hline Adjuvant Ref & Bacterial strain & Antibiotic & $\mathrm{MIC}^{\mathrm{a}}$ & $\mathrm{MIC}^{\mathbf{b}}(\mathrm{AD}$ & \\
\hline $\mathbf{3 4}^{104}$ & E. coli & $\begin{array}{l}\text { NOV } \\
\text { ERY }\end{array}$ & $\begin{array}{l}128 \\
64\end{array}$ & $\begin{array}{l}1(64) \\
4(64)\end{array}$ & 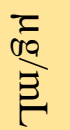 \\
\hline $\mathbf{3 5}^{104}$ & E. coli & $\begin{array}{l}\text { NOV } \\
\text { ERY }\end{array}$ & $\begin{array}{l}128 \\
64\end{array}$ & $\begin{array}{l}16(8) \\
16(8)\end{array}$ & 舀 \\
\hline \multirow{3}{*}{$3^{110}$} & E. coli AG100 & $\begin{array}{l}\text { CHL } \\
\text { CIP } \\
\text { TET } \\
\text { FEP } \\
\text { ERY }\end{array}$ & $\begin{array}{l}8 \\
0.25 \\
2 \\
0.5 \\
512\end{array}$ & $\begin{array}{r}0.5(0.4) \\
0.03(0.4) \\
0.125(0.4) \\
0.06(0.4) \\
256(0.4)\end{array}$ & 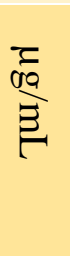 \\
\hline & P. aeruginosa PA01 & $\begin{array}{l}\text { CHL } \\
\text { CIP } \\
\text { TET } \\
\text { FEP } \\
\text { ERY }\end{array}$ & $\begin{array}{l}512 \\
16 \\
16 \\
8 \\
512\end{array}$ & $\begin{array}{r}16(3.2) \\
<1(3.2) \\
4(3.2) \\
1(3.2) \\
256(3.2)\end{array}$ & 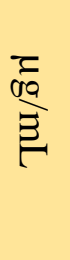 \\
\hline & E. aerogenes ATCC 13048 & $\begin{array}{l}\text { CHL } \\
\text { CIP } \\
\text { TET } \\
\text { FEP } \\
\text { ERY }\end{array}$ & $\begin{array}{l}4 \\
0.5 \\
2 \\
0.25 \\
512\end{array}$ & $\begin{array}{r}0.25(1.6) \\
0.015(1.6) \\
0.25(1.6) \\
0.03(1.6) \\
128(1.6)\end{array}$ & 吿 \\
\hline $37^{111}$ & $\begin{array}{l}\text { P. aeruginosa } \mathrm{PAO} 1 \\
\text { E. aerogenes EA289 }\end{array}$ & DOX & $\begin{array}{l}16 \\
40\end{array}$ & $\begin{array}{r}2(2) \\
0.5(2)\end{array}$ & 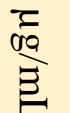 \\
\hline $\mathbf{3 8}^{112}$ & $\begin{array}{l}\text { E. aerogenes } \mathrm{EA} 289 \\
\text { P. aeruginosa } \mathrm{PAO} 1 \\
\text { K. pneumoniae KPC } 2\end{array}$ & DOX & $\begin{array}{l}40 \\
20 \\
10\end{array}$ & $\begin{array}{l}2(2.5 \mu \mathrm{M}) \\
2(2.5 \mu \mathrm{M}) \\
2(2.5 \mu \mathrm{M})\end{array}$ & 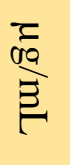 \\
\hline $39^{112}$ & $\begin{array}{l}\text { E. aerogenes } \mathrm{EA} 289 \\
\text { P. aeruginosa } \mathrm{PAO} 1 \\
\text { K. pneumoniae KPC2 }\end{array}$ & DOX & $\begin{array}{l}40 \\
20 \\
10\end{array}$ & $\begin{array}{r}2(5 \mu \mathrm{M}) \\
2(1.25 \mu \mathrm{M}) \\
2(2.5 \mu \mathrm{M})\end{array}$ & $\frac{\sqrt{10}}{\sqrt{0}}$ \\
\hline $\mathbf{4 3}^{113}$ & $\begin{array}{l}\text { E. aerogenes } \mathrm{EA} 289 \\
\text { P. aeruginosa } \mathrm{PAO} 1 \\
\text { K. pneumoniae KPC2 }\end{array}$ & DOX & $\begin{array}{l}25 \\
50 \\
\text { ND }\end{array}$ & $\begin{array}{l}2(6.25 \mu \mathrm{M}) \\
2(3.12 \mu \mathrm{M}) \\
2(3.12 \mu \mathrm{M})\end{array}$ & $\stackrel{\frac{\pi}{00}}{\frac{010}{2}}$ \\
\hline $\mathbf{4 4}^{115}$ & P. aeruginosa $\mathrm{PAO} 1$ & DOX & 32 & $2(1.22)$ & $\frac{2}{100}$ \\
\hline
\end{tabular}

${ }^{\mathrm{a}} \mathrm{MIC}$ of the antibiotic alone; ${ }^{\mathrm{b}} \mathrm{MIC}$ of the antibiotic in the presence of the adjuvant at the requested concentration $(\mu \mathrm{g} / \mathrm{mL}$ in parentheses); NOV: Novobiocin; ERY: Erythromycin; CHL: Chloramphenicol; CIP: Ciprofloxacin; TET: Tetracycline; FEP: cefepime; DOX: Doxycycline; ND: not determined.

Table 4. Mics of antibiotics in the presence of adjuvants 34-44 against Gram-negative bacteria 

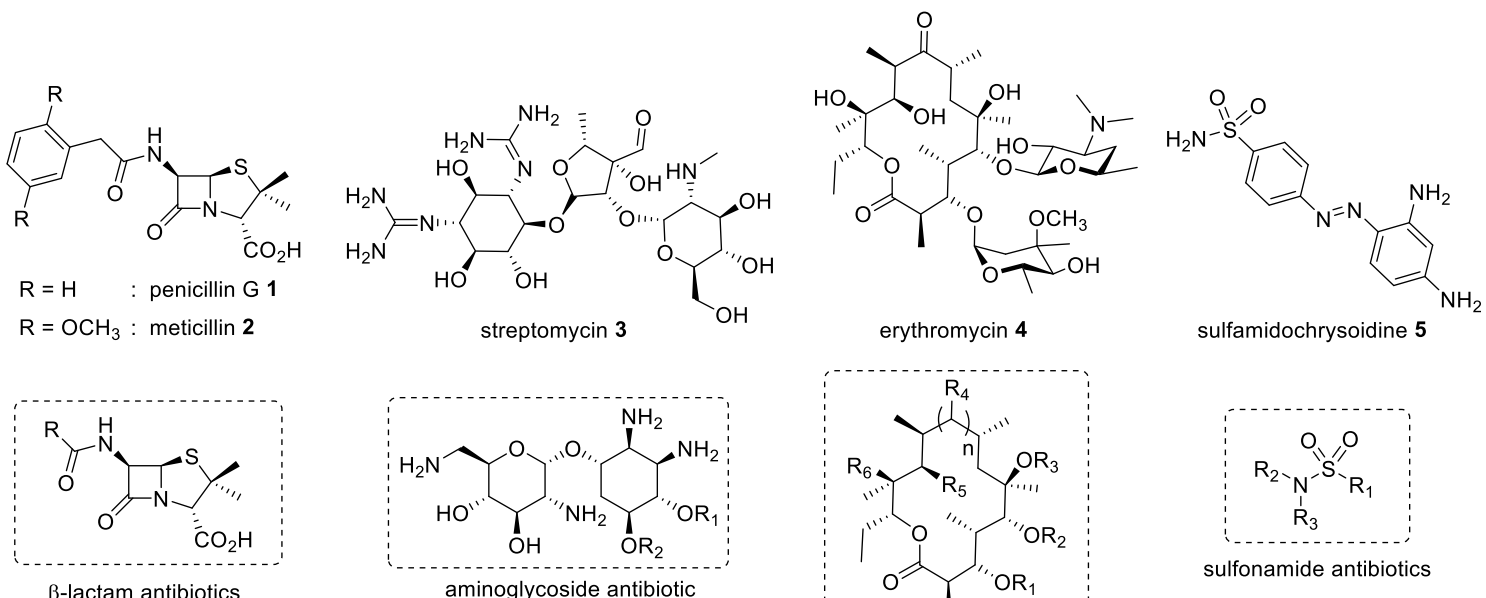

erythromycin 4

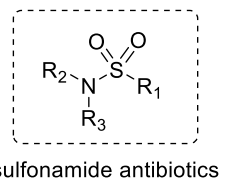

$\beta$-lactam antibiotics

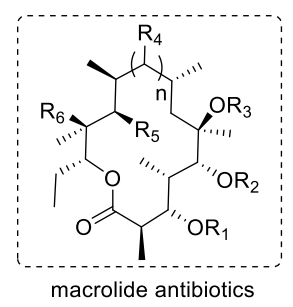

sulfonamide antibiotics
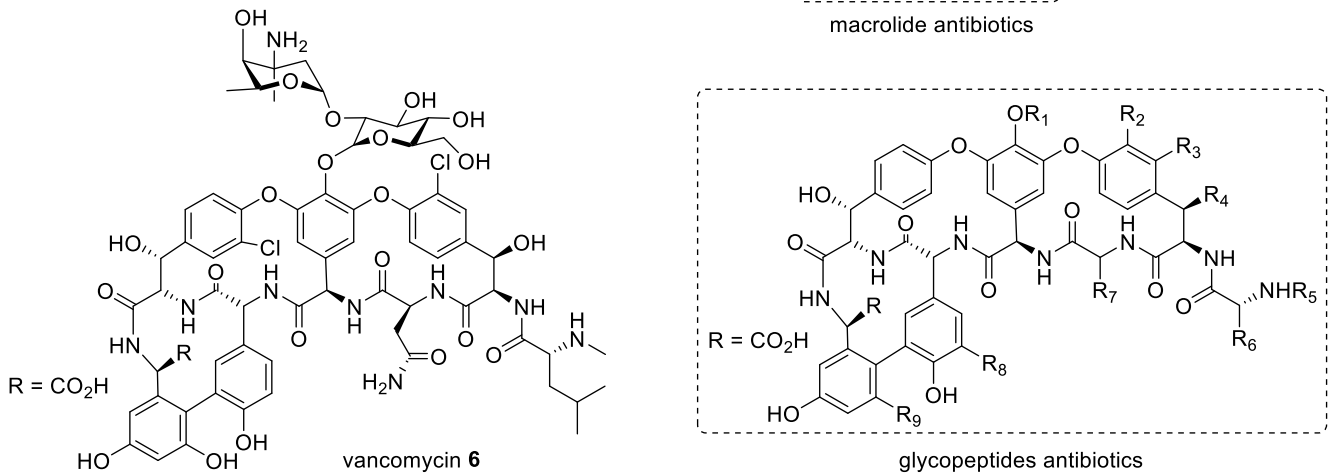

Figure 1. Structure of $\beta$-lactam antibiotics (1-2), streptomycin 3, erythromycin 4, sulfamidochrysoidine 5 and vancomycin 6 


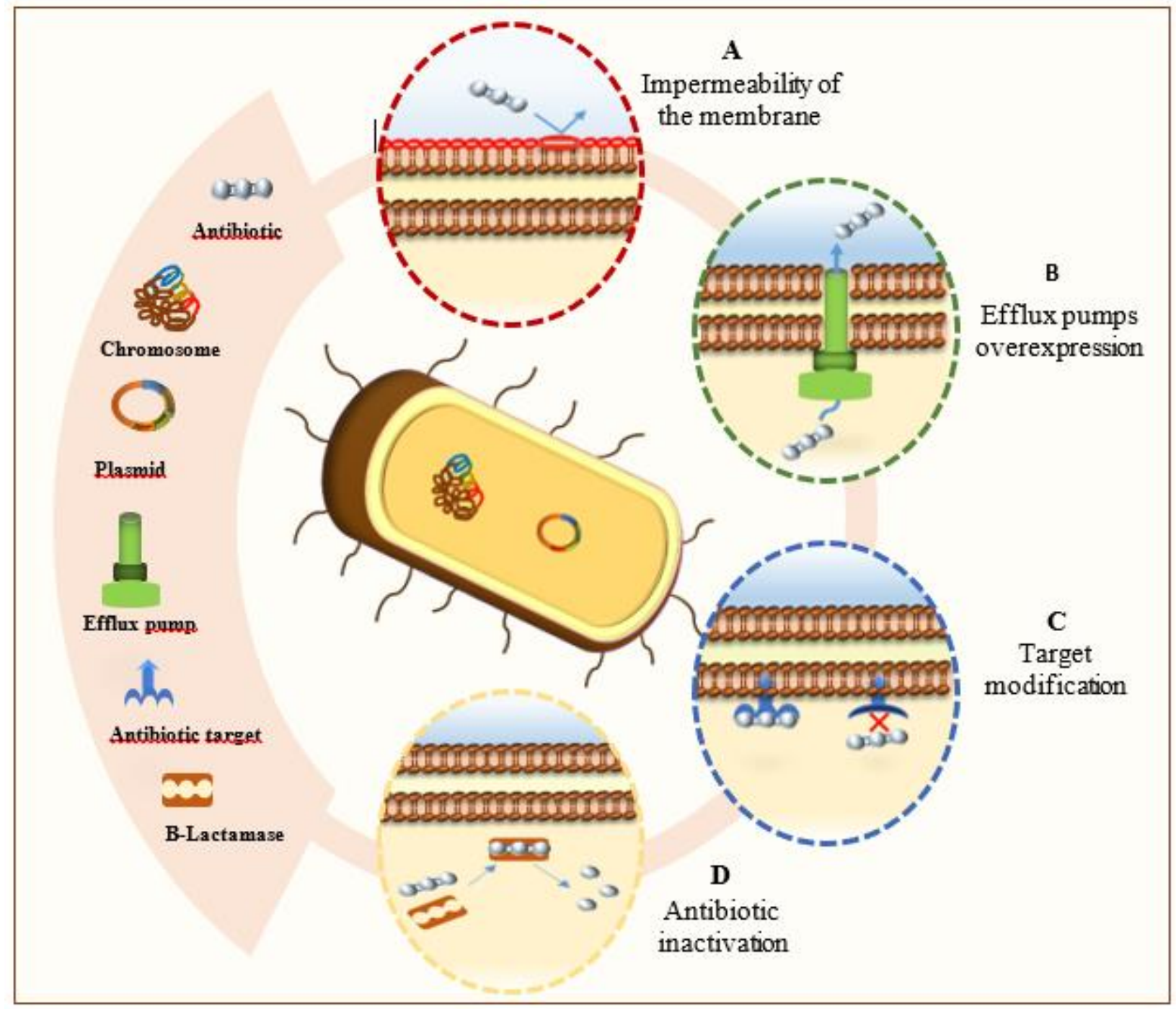

Figure 2. Antibiotics bacterial resistance mechanisms. A) The reduction of the membrane permeability prevents the entry of the antibiotic. B) Overexpression of pumps that expel the antibiotic outside of the cell. C) Modification of the antibiotic's target makes it unable to recognize it. D) Enzymatic inactivation of the antibiotic and loss of its activity 


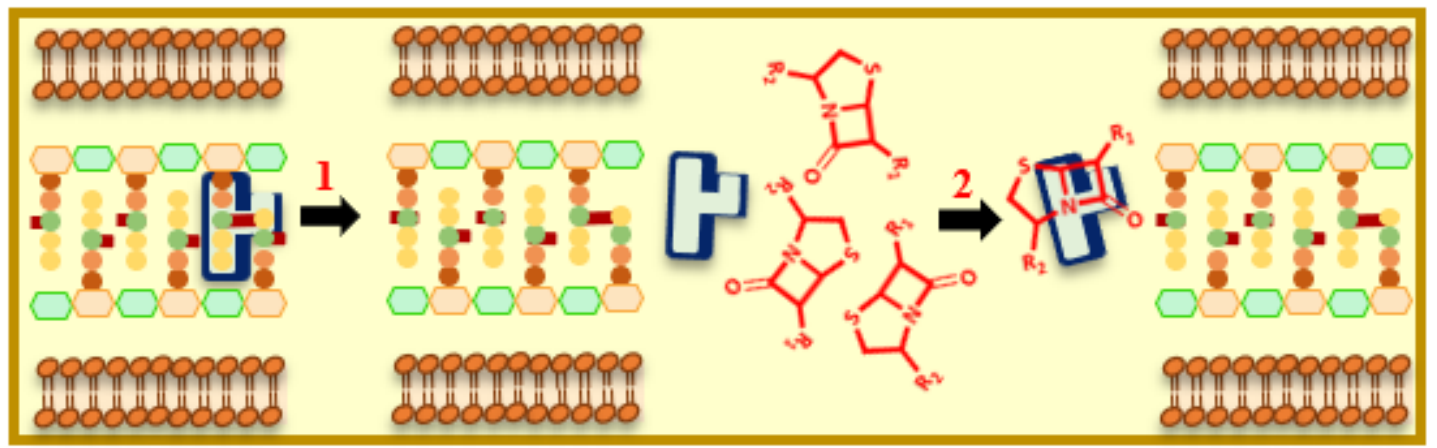

1. The Penicillin Binding Proteins ( $\mathrm{PBP}$ ), link the newly formed peptidoglycan with the old one.

2. Beta-lactam antibiotics inhibit the bacterial wall synthesis by binding to and blocking (PBPs)

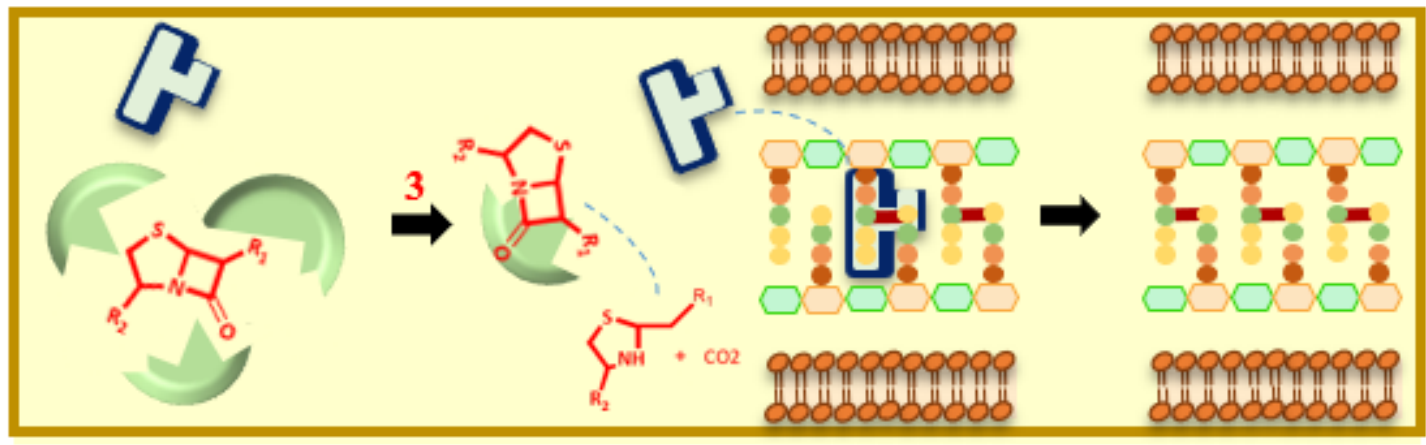

3. The bacterium resists the action of beta-lactams by secretion of $\beta$-lactamases which hydrolyze beta-lactams and so block their action.

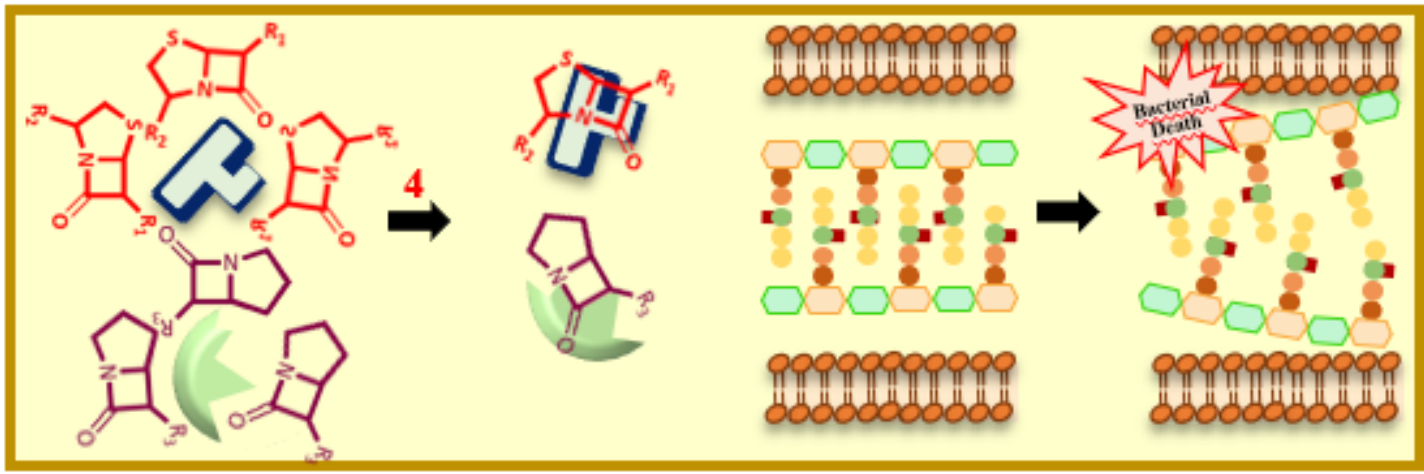

4. Inhibitors of beta-lactamases in turn, inhibit beta-lactamases restore beta-lactams' activity.

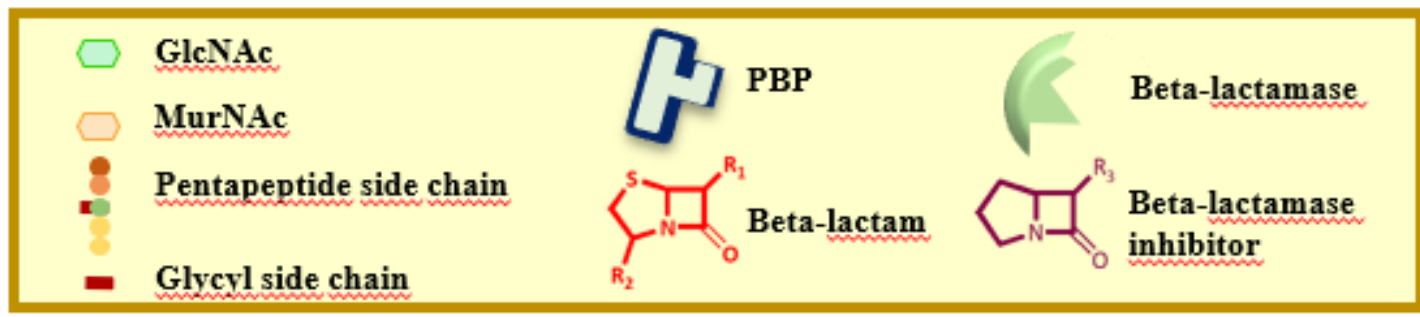

Figure 3. Mechanisms of action of beta-lactams, their inhibitors and their adjuvants 
<smiles>CC1(C)[C@H](C(=O)O)N2C(=O)C[C@H]2S1(=O)=O</smiles>

Sulbactam 7

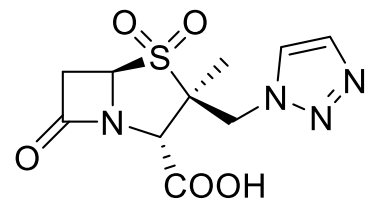

Tazobactam 8

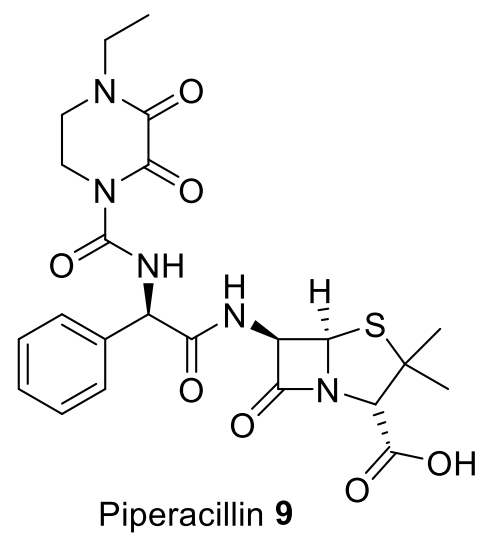

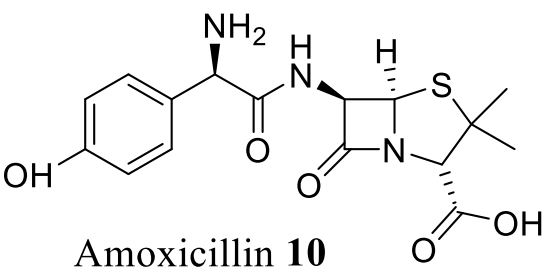<smiles>O=C(O)[C@H]1/C(=C\CO)OC2CC(=O)N21</smiles><smiles>CC1(C)S[C@@H]2[C@@H](NC(=O)C(C(=O)O)c3ccsc3)C(=O)N2[C@H]1C(=O)O</smiles><smiles>CC1(C)S[C@@H]2[C@H](NC(=O)[C@@H](N)c3ccccc3)C(=O)N2[C@H]1C(=O)O</smiles><smiles>NC(=O)[C@@H]1CCC2CN1C(=O)N2OS(=O)(=O)O</smiles>

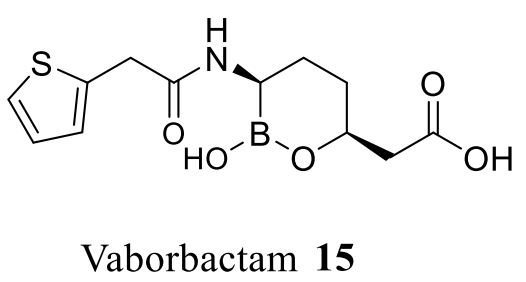

Figure 4. Structure of lactams 7-15 


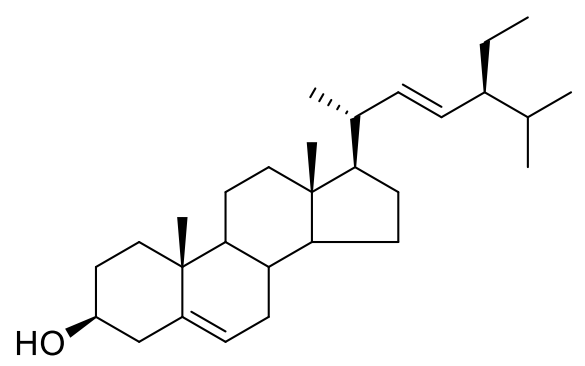

Stigmasterol 16

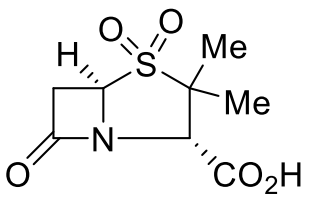

CP-45,899 17

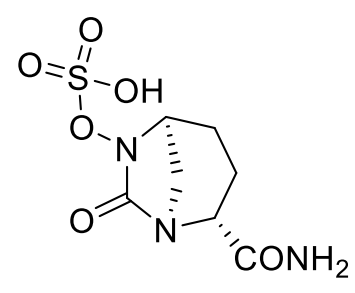

AVE1330A 18<smiles></smiles>

Cyclic Boronic 119<smiles>NCc1ccc(C(=O)N[C@@H]2Cc3cccc(C(=O)O)c3O[B-](O)(O)O2)cc1</smiles>

Cyclic Boronic $2 \mathbf{2 0}$<smiles>N[C@@H](CN[C@H](CN[C@H](CC(=O)O)C(=O)O)C(=O)O)C(=O)O</smiles>

Aspergillomarasmine A 21<smiles>CC1(C)C[C@H]1C(=O)NC(=CCCCCSCC(N)C(=O)O)C(=O)O</smiles>

Cilastatin 22<smiles>O=C(NC1CCNCC1)[C@@H]1CCC2CN1C(=O)N2OS(=O)(=O)O</smiles>

Relebactam (MK-7655) 23

Figure 5. Structure of derivatives 16-23 
<smiles>[R16][R16]([H])([H])O[Na]</smiles><smiles>Cc1c([N+](=O)[O-])ccc2c(NCCN3CCCCC3)ccnc12</smiles>
ethyl] aminoquinoline 25<smiles>CC(C)CCOC1=CC(C(N)=O)=CC2C=CC=CC12</smiles>

4-isopentyloxy-2-naphthamide $\mathbf{2 7}$<smiles>O=C(O[C@H]1Cc2c(O)cc(O)cc2O[C@@H]1c1ccc(O)c(O)c1)c1cc(O)c(O)c(O)c1</smiles>

EGCG 29<smiles>O=C1NC(=O)C(Br)=C1Br</smiles>

3.4-dibromopyrrole-2.5-dione $\mathbf{2 8}$<smiles>N=C(N)NCCC[C@H](NC(=O)[C@@H](N)Cc1ccccc1)C(=O)Nc1ccc2ccccc2c1</smiles>

PA $\beta$ N 30

Figure 6. Structure of derivatives 24-30 


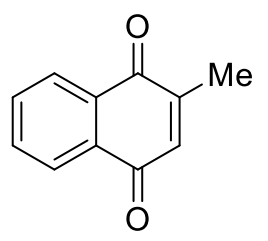

\section{Menadione 31}

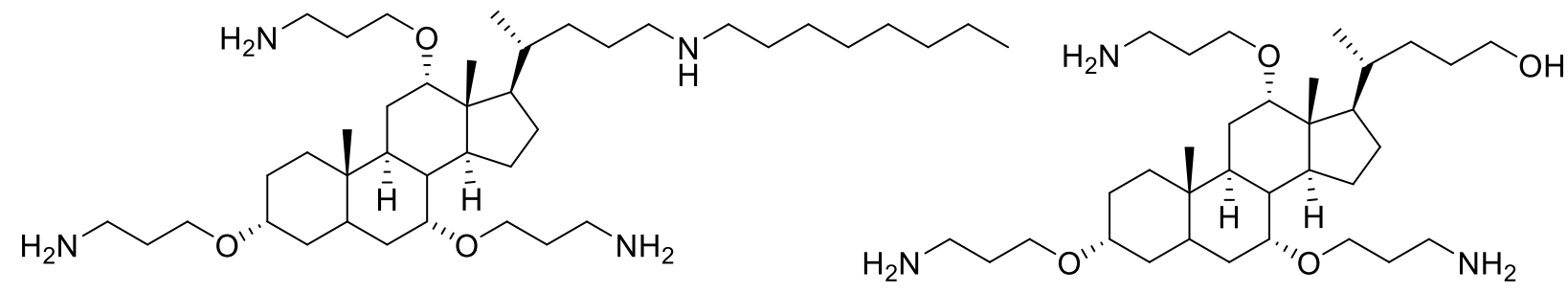

CSA-13 32

CSA-8 33

Figure 7. Structure of Menadione 31, CSA-13 32 and CSA-8 33 


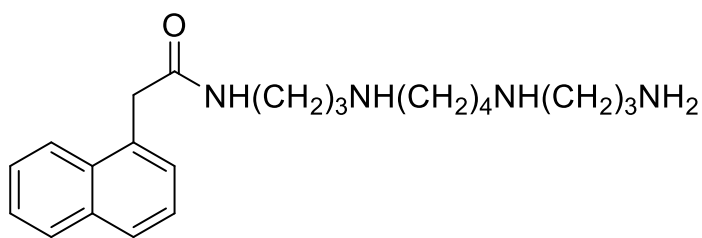

Naphthylacetylspermine $\mathbf{3 4}$<smiles>CC(C)[C@H](CC[C@H](C)C1CCC2C3C(CCC21C)C1(C)CC[C@@H](NCCC[NH2+]CCCCN)CC1C[C@H]3O)OS(=O)(=O)O</smiles>

Squalamine 36

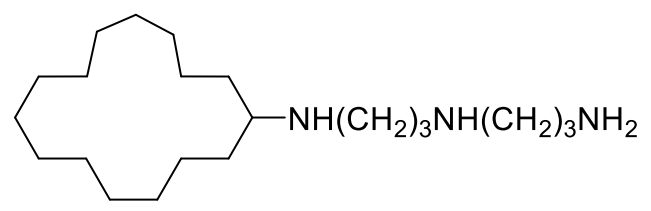

MOTU-N33 38

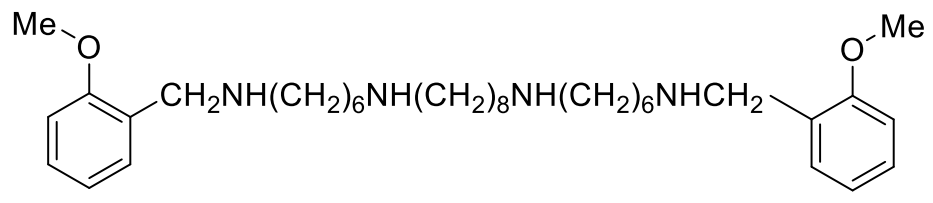

Methoctramine 35

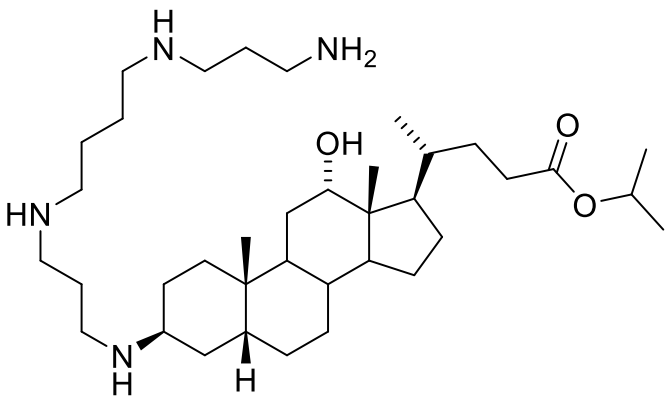

Claramine A1 37

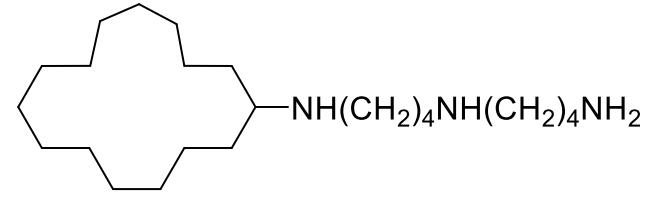

MOTU-N44 39<smiles>COc1c(Br)cc(/C=C/C(=O)NCCCNCCCCNCCCN)cc1Br</smiles><smiles>COc1c(Br)cc(/C=C/C(=O)NCCCNCCCCN)cc1Br</smiles><smiles>COc1c(Br)cc(/C=C/C(=O)NCCCNCCCNCCCNC(=O)/C=C/c2cc(Br)c(OC)c(Br)c2)cc1Br</smiles><smiles>COc1c(Br)cc(/C=C/C(=O)NCCCN(CCCN)CCCN)cc1Br</smiles><smiles>CC(C)=CCC/C(C)=C\CC/C(C)=C\CNCCCNCCCCNCCCN</smiles>

Figure 8. Structure of polyamino derivatives 34-44. 